\title{
Geophysical evidence for a transform margin offshore Western Algeria: a witness of a subduction-transform edge propagator?
}

\author{
Rabia Badji, ${ }^{1,2,3}$ Philippe Charvis, ${ }^{2}$ Rabah Bracene, ${ }^{1}$ Audrey Galve, ${ }^{2}$ Madjid Badsi, \\ Alessandra Ribodetti, ${ }^{2}$ Zahia Benaissa, ${ }^{3}$ Frauke Klingelhoefer, ${ }^{4}$ Mourad Medaouri ${ }^{1}$ \\ and Marie-Odile Beslier ${ }^{2}$ \\ ${ }^{1}$ Sonatrach, Division exploration, Bât C, Avenue du $1^{\mathrm{er}}$ Novembre, B.P 68M, Boumerdes, Algeria. E-mail: badji@geoazur.unice.fr
2 Université Nice Sophia Antipolis, IRD, CNRS, Observatoire de la Côte d'Azur, Géoazur, 250 rue Albert Einstein, F-06560, Sophia Antipolis, France
${ }^{3}$ Université des sciences et de la technologie Houari Boumediene, USTHB, FSTGAT, el-alia Algiers, Algeria
${ }^{4}$ Ifremer, Department of marine Geosciences, ZI de la Pointe de Diable, CS10070, Plouzané, France
}

Accepted 2014 November 19. Received 2014 November 17; in original form 2014 September 23

\begin{abstract}
SUMMAR Y
For the first time, a deep seismic data set acquired in the frame of the Algerian-French SPIRAL program provides new insights regarding the origin of the westernmost Algerian margin and basin. We performed a tomographic inversion of traveltimes along a 100-km-long wide-angle seismic profile shot over 40 ocean bottom seismometers offshore Mostaganem (Northwestern Algeria). The resulting velocity model and multichannel seismic reflection profiles show a thin (3-4 km thick) oceanic crust. The narrow ocean-continent transition (less than $10 \mathrm{~km}$ wide) is bounded by vertical faults and surmounted by a narrow almost continuous basin filled with Miocene to Quaternary sediments. This fault system, as well as the faults organized in a negative-flower structure on the continent side, marks a major strike-slip fault system. The extremely sharp variation of the Moho depth (up to $45 \pm 3^{\circ}$ ) beneath the continental border underscores the absence of continental extension in this area. All these features support the hypothesis that this part of the margin from Oran to Tenes, trending $\mathrm{N} 65-\mathrm{N} 70^{\circ} \mathrm{E}$, is a fossil subduction-transform edge propagator fault, vestige of the propagation of the edge of the Gibraltar subduction zone during the westward migration of the Alborán domain.
\end{abstract}

Key words: Seismic tomography; Continental margins: transform; Crustal structure; Africa; Europe.

\section{INTRODUCTION}

The Algerian margin is part of the western Tethyan Domain. Beginning in the Late Oligocene, the closure of the Tethyan Ocean along a north to northwest dipping subduction zone produced the coeval opening of backarc oceanic basins (e.g. present-day oceanic basins of the western Mediterranean domain; Fig. 1). The continental forearc of this subduction, of European origin, drifted southeastward and collided with the North African margin (Réhault et al. 1984; Lonergan \& White 1997; Frizon de Lamotte et al. 2000; Jolivet \& Faccenna 2000), creating an almost continuous orogenic belt (named the Maghrebides in Northern Africa) spanning from Gibraltar to Calabria (insets Fig. 1). To the west, the Alborán forearc was migrating westward, from middle to late Miocene, with the concomitant opening of the Algerian-Balearic basin (Acosta et al. 2001; Mauffret et al. 2004) as the backarc basin of the Gibraltar subduction zone (Rosenbaum et al. 2002; Camerlenghi et al. 2008; Gutscher et al. 2012).
Although this general scheme driven by subduction rollback is widely accepted, many questions remain unanswered regarding the kinematic evolution of the western Mediterranean region. The palaeoreconstruction of the Alborán block is controversial and it implies diverse types of margins (extensional or strike-slip margins) and timing of seafloor emplacement (Bouillin 1986; Frizon de Lamotte et al. 2000; Rosenbaum et al. 2002; Mauffret et al. 2004; Domzig et al. 2006; Schettino \& Turco 2006). Three different tectonic scenarios exist for the past $35 \mathrm{Ma}$ (Chertova et al. 2014) which are consistent either with the western Algerian margin being a passive margin (e.g. Jolivet et al. 2009; Vergés \& Fernàndez 2012) or the trace of an E-W lithosphere tearing (e.g. Rosenbaum et al. 2002; Spakman \& Wortel 2004; Chertova et al. 2014; van Hinsbergen et al. 2014). This on-going debate is largely due to the lack of deep geophysical data in the Algerian Basin and along the Algerian margin.

Our study area is located along the Western Algerian margin, at the transition between the margin of the Alborán Sea and the margin 


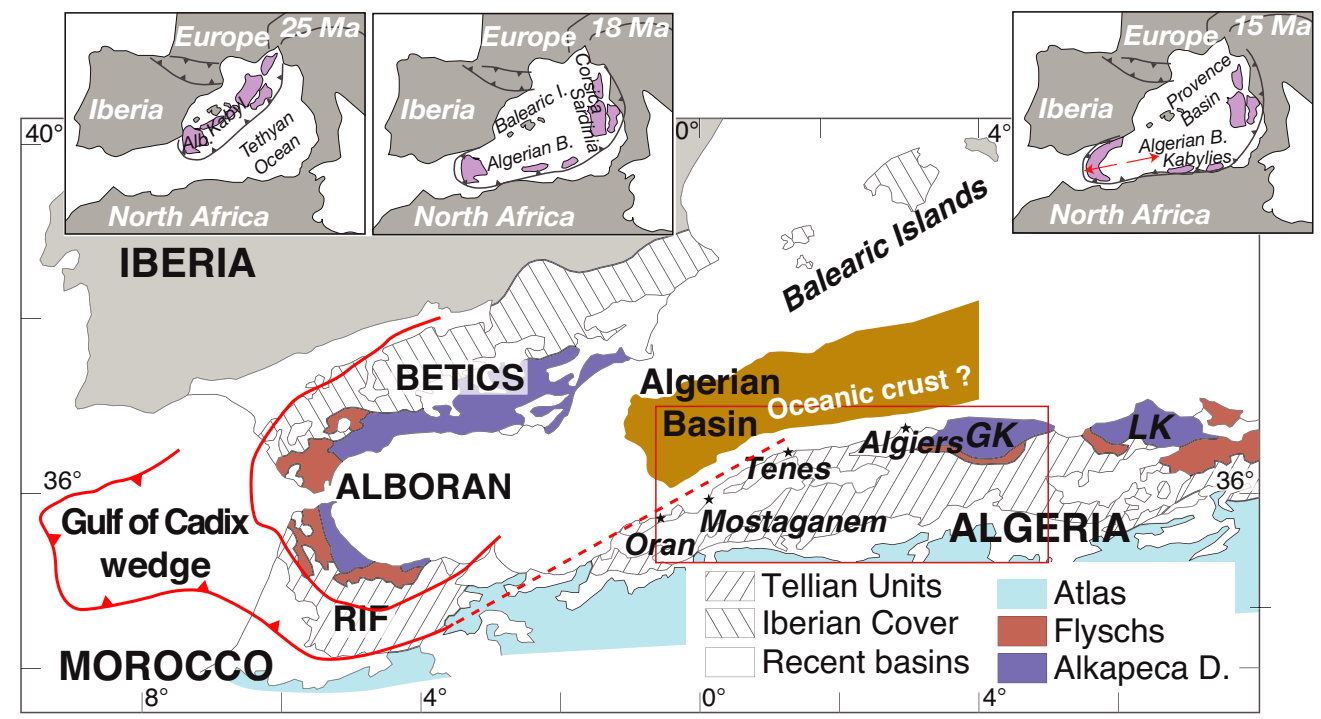

Figure 1. Tectonic sketch of the western Mediterranean after (Comas et al. 1999) showing Neogene extensional basins and major tectonic units. The major thrust and the Gibraltar subduction are from (Gutscher et al. 2012; Vergés \& Fernàndez 2012). GK, Great Kabylia; LK, Lesser Kabylia. AlKaPeCa D, internal zones domain. The red rectangle delimits the study area located in northwestern Algeria. The insets show a summary of the reconstruction of the tectonic evolution of the western Mediterranean since the Oligocene (Rosenbaum et al. 2002).

of the Algerian Basin eastward (Fig. 1). It was previously surveyed during the MARADJA cruise in 2003 (Domzig et al. 2006) using shallow seismic imaging and swath bathymetry, and also by several industrial seismic reflection surveys. As part of an Algerian-French cooperative program, the SPIRAL cruise was conducted on board the R/V Atalante (Ifremer) in 2009 September-October. For the first time wide-angle seismic (WAS) reflection, refraction data and deep multichannel seismic (MCS) reflection data were acquired in order to image the deep structure of the Algerian margin. The main aims of the survey were to explore the deep crustal structure of the complete margin in order to better constrain the opening of the Algerian Basin, to identify possible indicators of recent reactivation of the margin, to characterize the nature of the crust and to assess the petroleum potential of the neighbouring sedimentary basins.

The lithospheric tearing and the rollback of the plate subducting beneath the Gibraltar arc created a major lithospheric fault, which propagated westward. This feature was stable with time, acting as the strike slip fault bounding the Alborán block and the Algerian Basin to the south. This new type of plate boundary named STEP for Subduction-Transform Edge Propagator (Govers \& Wortel 2005) is still poorly known. The western Algerian margin and basin will provide some new insights on the deep structure of this STEP fault.

In this paper, we present the interpretation of a joint 2-D refraction and wide-angle reflection traveltime tomography model along a profile shot offshore Mostaganem, together with regional SPIRAL and industrial MCS sections, and available bathymetric data, in order to image the deep structure of the Mostaganem margin segment.

\section{GEODYNAMIC FRAMEWORK OF THE ALGERIAN BASIN}

The southern Mediterranean sea is bounded in northern Algeria by an Alpine orogenic belt resulting from the collision of continental fragments of European origin with the North African margin
(Durand-Delga \& Fontboté 1980; Bouillin 1986; Frizon de Lamotte et al. 2000; Bracène \& Frizon de Lamotte 2002; Fig. 1).

Onshore, the Mostaganem area from Tenes to Oran (Fig. 2) is considered as part of the external zones (also named the Tellian domain, Fig. 1). The outcrops consist of Miocene and Quaternary sediments, composed of marls, limestone, sandstones and gypsum (Perrodon 1957; Polvêche 1959; Thomas 1985) which are well known in the Chelif Basin (south of Mostaganem, Fig. 2). Owing to the lack of subsurface data, the nature of the basement beneath the Miocene deposits is still unknown in the Mostaganem area. To the north, the upper part of the Miocene sedimentary series is encountered in the Arzew-1 well, drilled in the 1970 s on the shallow shelf northwest of Mostaganem (Medaouri et al. 2012; Fig. 2).

The opening of the Algerian Basin, between the Balearic Islands and the Algerian margin, as the western prolongation of the Provence Basin, is still a matter of debate. The NW-SE opening of the Provence Basin started $23 \mathrm{Ma}$ as a backarc basin of the Tethyan subduction beneath Africa (Fig. 1). According to Schettino \& Turco (2010), the Algerian Basin opened during the last phase of rotation of Sardinia and Corsica (19 Ma). An alternative hypothesis is an E-W opening, from 16 to $8 \mathrm{Ma}$, associated with the westward migration of the Alborán domain (Comas et al. 1992; Platt et al. 1998; Comas et al. 1999; Rosenbaum et al. 2002; Mauffret et al. 2004, 2007; Booth-Rea et al. 2007; Medaouri et al. 2014; Fig. 1). This second hypothesis is preferred by many authors even if the distance of the westward migration of the Alborán domain is debated and ranges from $\sim 200$ to $\sim 700 \mathrm{~km}$ (Michard et al. 2002; Platt \& Houseman 2003; Duggen et al. 2004; Mauffret et al. 2004; Platt et al. 2006; Medaouri et al. 2014). In this case the west Algerian and the Moroccan margins were structured by the retreat of the westward migration of the southern edge of the Gibraltar subduction zone (Lonergan \& White 1997; Faccenna et al. 2001; Chalouan \& Michard 2004; Govers \& Wortel 2005).

The recently acquired seismic data of the SPIRAL project will provide new constrains on the opening of the Algerian Basin. The structural direction of the Algerian margin changes from $\mathrm{N} 65^{\circ} \mathrm{E}$ to $\mathrm{N} 70^{\circ} \mathrm{E}$ west of Tenes to $\mathrm{N} 85^{\circ} \mathrm{E}$ east of Tenes (Fig. 2). To the 


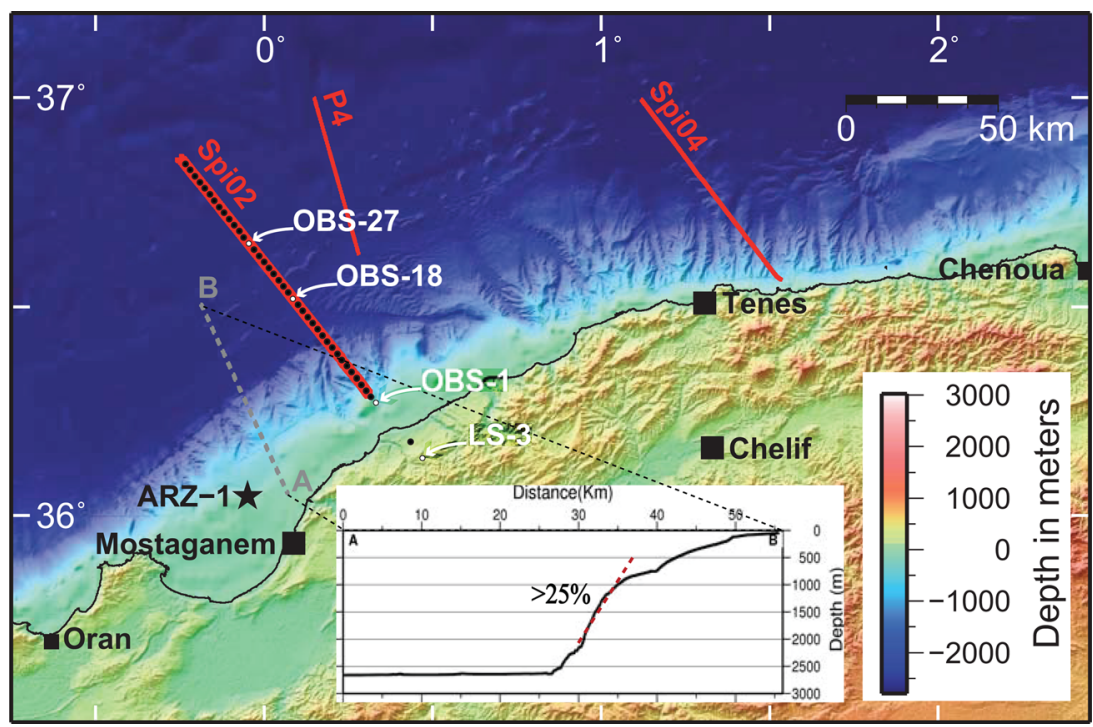

Figure 2. Bathymetric and topographic map of the western Algerian margin. Seafloor bathymetry ( $50 \mathrm{~m}$ digital elevation model) derived from satellite altimetry and from swath bathymetric data collected during the MARADJA cruise (Domzig et al. 2006). Red lines mark multichannel seismic profiles and black dots location of the seismometers on land and at sea. The white dots are labelled and indicate the positions of seismometers shown in Fig. 3. Grey line A-B marks the bathymetric profile shown in inset which highlights the steep continental slope. ARZ-1 is a commercial well drill located in Arzew bay.

east the deep structure of the margin exhibits a large continental tilted block, the Khayr-al-Din Bank, consistent with a rifted margin whereas the very narrow ( $10 \mathrm{~km}$ or less) ocean-continent transition (OCT) suggest the margin is possibly a purely strike-slip type margin formed as a STEP fault system (Leprêtre et al. 2011, 2013). The authors propose a multiphased emplacement of the margin with the $\sim$ NW-SE extension associated with the opening of the Central Algerian Basin and a more recent transcurrent episode induced by the westward migration of the Alborán block.

Whereas most of the Algerian margin undergoes present-day NW-SE compression (Stich 2003), there is no clear offshore evidence for active deformation related to this compression along the westernmost part of the Algerian margin (Domzig et al. 2006). Onshore, earthquake focal mechanisms support a NW-SE compressional stress in the Oran-Mascara-El Asnam (named Chelif since the M 7.2 El Asnam earthquake in 1980) area (Meghraoui et al. 1986, 1996; Yielding et al. 1989).

In this geodynamic framework, the Mostaganem area represents a key zone, which can potentially provide insights into the structure and evolution of the Western Mediterranean from Miocene to present.

\section{DATA SET}

\subsection{SPIRAL wide-angle seismic data}

To probe the crustal structure of the margin, a $\sim 100$-km-long wideangle seismic profile perpendicular to the shore was acquired during the SPIRAL cruise (2009 October-November). 35 MicrOBS ocean bottom seismometers (OBS; Auffret et al. 2004) and five $(\mathrm{OBH})$, belonging to Ifremer and the University of Bretagne Occidentale (UBO) were deployed offshore Mostaganem, from the N/O Atalante, at $1.9 \mathrm{~km}$ intervals in average (Fig. 2). Several land stations were deployed, but only few of them recorded useful data. In this paper, we used land stations LS2 and LS3 located, respectively, at 14 and $21 \mathrm{~km}$ from the southernmost OBS (Fig. 2). These seismometers recorded 489 shots every 60 s leading to $\sim 150 \mathrm{~m}$ in- tervals. The seismic source array for the wide-angle seismic profile had a total volume of $1461\left(8909 \mathrm{in}^{3}\right)$ and was composed of eight airguns with an individual volume of 161 , and two airguns with a volume of 91 . All seafloor instrument data were corrected for the clock drift during the recording period. The spatial drift between the deployment location and the seafloor location was estimated from the inversion of direct water wave traveltimes. The pre-processing sequence of data includes frequency filters, a minimum phase spectral deconvolution and an automatic gain control (see Figs 3 and S1 for more details).

\subsection{MCS data}

Two MCS sections were shot during the SPIRAL cruise across the margin offshore Mostaganem. Section Spi02 is coincident with the WAS profile previously described whereas profile Spi04 $(\sim 80 \mathrm{~km}$ long) is parallel but located $104 \mathrm{~km}$ to the east (Fig. 2). The seismic lines were shot using an array of 13 airguns with a total volume of $3099 \mathrm{in}^{3}$. In order to strengthen low-frequencies, the source was tuned in single-bubble mode (Avedik et al. 1993). This technique enhances low frequencies and thereby improves signal penetration and subsalt deposits imaging. The seismic source was fired every $20 \mathrm{~s}$, leading to a shot spacing of $\sim 50 \mathrm{~m}$ along both lines. The data were recorded using a $4.5-\mathrm{km}$-long streamer, 360 channel groups providing 45 fold coverage and $6.25 \mathrm{~m} \mathrm{CDP}$ (common depth point) spacing. The recording length was 17 seconds two-way traveltime (stwt) with a 4 ms sampling rate.

To further improve the quality of the seismic images issued from the on-board initial processing, we applied the following processing sequence to the data using Geocluster software (a CGG Veritas package): (1) a zero-phasing of single bubble wavelet, (2) an inverse Q filter (phase only) to remove the non-stationary phase components of the data (Varela et al. 1993), (3) a pre-stack surface multiple modelling also known as SRME (surface related multiple elimination), followed by an adaptive subtraction from the data (Berkhout \& Verschuur 1997; Verschuur \& Berkhout 1997), (4) a velocity analysis, (5) a second pass of multiple attenuation 

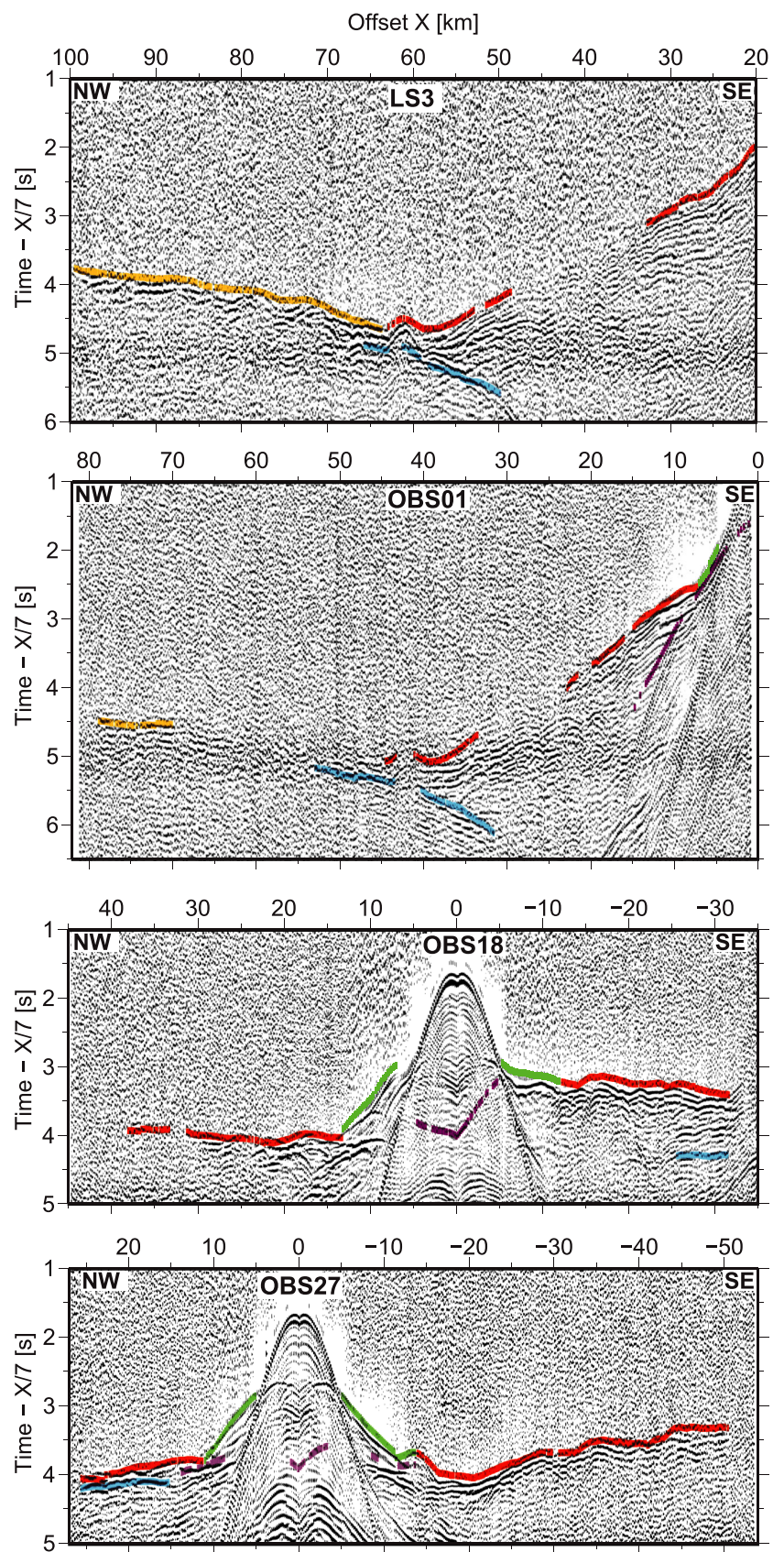

Figure 3. Examples of recorded wide-angle seismic sections. Each section was processed including a debias filter, a minimum phase spectral deconvolution, a 4-15 Hz Butterworth band-pass filter and a $2 \mathrm{~s}$ window length automatic gain control (AGC). The section are presented with a $7 \mathrm{~km} \mathrm{~s}^{-1}$ velocity reduction. For each section (LS3, land station 3, and OBS-01, 18 and 27 from top to bottom) traveltimes calculated in the final model (Figs 4 and 7) are superimposed. Green: Psed refracted in the sedimentary cover, red: Pg refracted in the crust, orange: Pn refracted in the upper mantle, violet: Prb reflected from the top of the basement and blue: PmP reflected from the Moho.

using a predictive-subtraction process, (6) a Kirchhoff pre-stack time migration, (7) an external mute, (8) a stack, (9) a 5-60 Hz bandpass filter and (10) a $500 \mathrm{~ms}$ automatic gain control.

In the western part of the Algerian offshore, Sonatrach acquired a set of seismic reflection data (Cope 2003) using a 6-km-long seismic streamer (480 channels of $12.5 \mathrm{~m}$ ) and a $3000 \mathrm{in}^{3}$ air-gun source fired at $50 \mathrm{~m}$ interval. The processing sequence is described in Medaouri et al. (2014). Several sections available in the study area were used to discuss the extension of the structure described along profile Spi02 and to discuss the Mostaganem margin deep structure.

\section{JOINT REFRACTION AND REFLECTION TRAVELTIME TOMOGRAPHY}

\subsection{Methodology}

Using refracted first arrivals and reflections observed on wide-angle seismic data, we construct a $2-D$ velocity model of the sedimentary layers, the igneous crust and the geometry of the Moho, using the joint refraction and reflection traveltime tomographic code tomo2d (Korenaga et al. 2000). Refracted first arrivals as well as reflections from the Moho (PmP) were identified and correlated between the different OBS sections (Fig. 3). The reflection from the top of the basement (Prb) was also identified by a careful correlation between each OBS and the coincident MCS profile at null offset (Fig. S2). Approximately 11000 arrivals were picked. The picking uncertainty associated to Psed and Pg arrival times (waves refracted, respectively, in the sedimentary cover and in the igneous crust) were between $16 \mathrm{~ms}$ (representing approximately twice the sampling rate) and $95 \mathrm{~ms}$ (representing approximately the dominant period of arrivals at far offsets) for the arrivals with high and low quality signal-to-noise ratio, respectively. The picking uncertainties for the reflected second arrivals were set to $100 \mathrm{~ms}$ which represents approximately one period of the signal.

The 2-D velocity field is parameterized as a sheared mesh hanging beneath the seafloor-land surface. An initial 1-D average velocity model is determined by forward modelling and extrapolated along the 2-D line beneath the topography (Korenaga et al. 2000). The code allows the simultaneous inversion of traveltimes from refracted first arrivals and from a reflected phase, to obtain a velocity model and the geometry of a floating reflector defined as an array of linear segments independent of the velocity grid (Korenaga et al. 2000).

To obtain the best 2-D velocity model we performed a top-tobottom layer stripping strategy consisting of adding the data sequentially as described in Sallarès et al. (2011, 2013a). During this procedure the damping was applied automatically if the velocity perturbation exceeds the maximum allowed value (10 per cent in our case; Korenaga et al. 2000).

We started with the sediment phases alone (Psed refracted in the sedimentary cover and Prb reflected from the acoustic basement). During this first step of the inversion the initial basement interface was chosen as a horizontal reflector at $5 \mathrm{~km}$ depth. In a second step we inverted the phase refracted in the basement $(\mathrm{Pg})$ and the phase reflected from the Moho (PmP). For this second phase, the initial velocity model was the result of the inversion of sediment phases above the top of the basement and the model resulting from the initial extrapolation of the 1-D average velocity model below it. Because of the steep topography of the Moho, the initial model was a 2-D dipping interface obtained by forward modelling (Fig. S3). In the last step we used the crustal velocity model and a constant velocity of $8.2 \mathrm{~km} \mathrm{~s}^{-1}$ in the upper mantle as initial model and incorporated Pn phases in the inversion to define the uppermost mantle velocity field. Because Pn phases are observed only on OBS 1 and on land stations at the southern end of the profile (Fig. 3), velocities in the upper mantle are only poorly constrained and will not be discussed in this paper. 


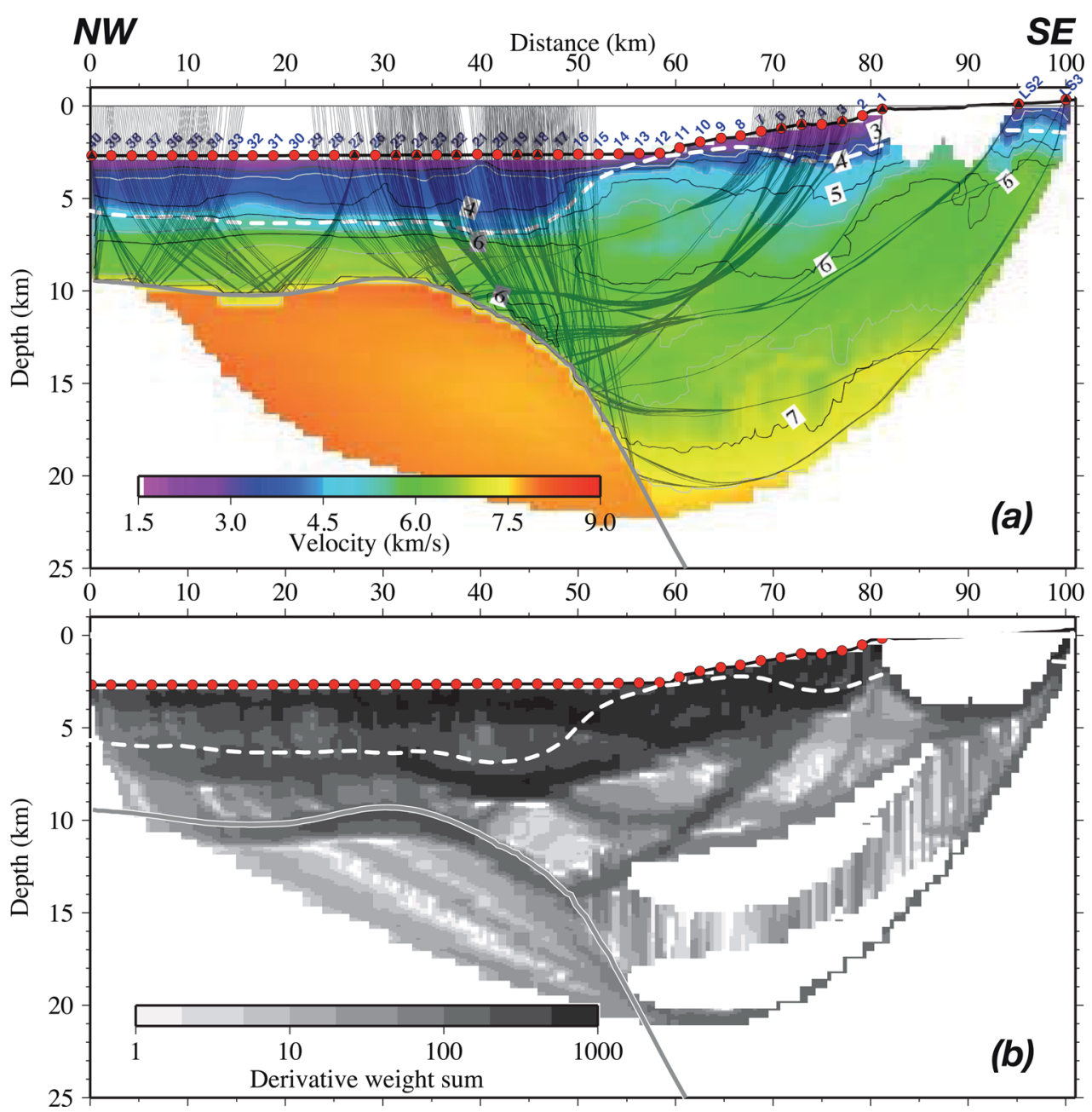

Figure 4. Result of the inversion of the wide-angle seismic traveltimes based on a layer strategy (Sallarès et al. 2011, 2013a). The model was obtained by the inversion of the Ps, Prb, Pg, PmP and Pn phases with the joint refraction, reflection traveltime tomography tomo2d code (Korenaga et al. 2000). (a) Final velocity model of the crust and upper mantle. The geometry of the top of the basement and the Moho are indicated, respectively, in white dashed line and in black. Rays reflected from the Moho are indicated in grey. (b) The derivative weight sum (DWS) which indicates the ray density clearly shows that the upper mantle is poorly sampled because only OBS 1 and land-stations 2 and 3 recorded Pn phase. Therefore the velocity in the upper mantle is not properly constrained. Red circles display the location of the OBSs, OBHs and land stations used in this work. Numbers in blue refer to seismometers.

A key advantage of this strategy is that it allows including sharp velocity contrasts across geological boundaries, rather than unrealistically smoothed velocity gradients required in traveltime tomography (Sallarès et al. 2011). On the other hand it requires the $a$ priori interpretation of the origin of the observed first arrival seismic phase, which might be partly subjective. Because we observed mostly the pre-critical and critical PmP in our data set (Fig. 3) it is rather difficult to determine accurately when first arrivals change from Pg to Pn. We nevertheless assume that beyond the critical distance, marked by the maximum amplitude of the PmP, the first arrival were Pn refracted in the upper mantle (see section LS3 and OBS1 in Fig. 3).

The best velocity model is obtained after 10 iterations for the inversion of each layer. The final rms is $64 \mathrm{~ms}$ and the chi-square value $\left(\chi^{2}\right) 1.7$ for the crust and mantle arrivals (Fig. 4 and Table 1). The upper $8 \mathrm{~km}$ of the crust are well sampled from km- 0 to $\mathrm{km}-80$ whereas the lower crust, the upper mantle, and the southern part of the model are poorly sample by rays (Fig. 4). To further assess our final velocity model we evaluated its reliability and resolution using a Monte Carlo simulation and checkerboard tests, respectively.

\subsection{Analysis of the uncertainties of the model}

In order to estimate uncertainties of the final model we performed a Monte Carlo analysis (Tarantola 1987). Practically we inverted 100 sets of traveltimes, with random Gaussian noise added to the initial data set ( $\pm 50 \mathrm{~ms}$ for the phase errors and $\pm 10 \mathrm{~ms}$ for the shot errors) with 100 random initial models (Korenaga et al. 2000; Sallarès et al. 2003). The set of $1001-\mathrm{D}$ initial velocity models is constructed by randomly perturbing velocity and reflector depth in the initial models within reasonable bounds. Practically, we added randomly varying velocities $\left( \pm 0.5 \mathrm{~km} \mathrm{~s}^{-1}\right)$ to several nodes at representative depths of the 1-D average model (Fig. S3). The 1-D velocity model is then extrapolated along the 2-D model. Similarly, we added random depth $( \pm 1 \mathrm{~km})$ to the ends of the 2-D initial Moho, and linearly interpolated this variation at each node of the interface (Fig. S3).

Finally, a 2-D inversion is performed for each random initial model with a specific data set with Gaussian noise added. We compute the average of all the Monte Carlo realizations (Fig. 5a) and the standard deviations of velocity and depth parameters (Fig. 5b). The standard deviations of such an ensemble can be interpreted 
Table 1. Parameters used during the inversion. Several values of the inversion parameters were tested and this table summarize the values providing the best final model.

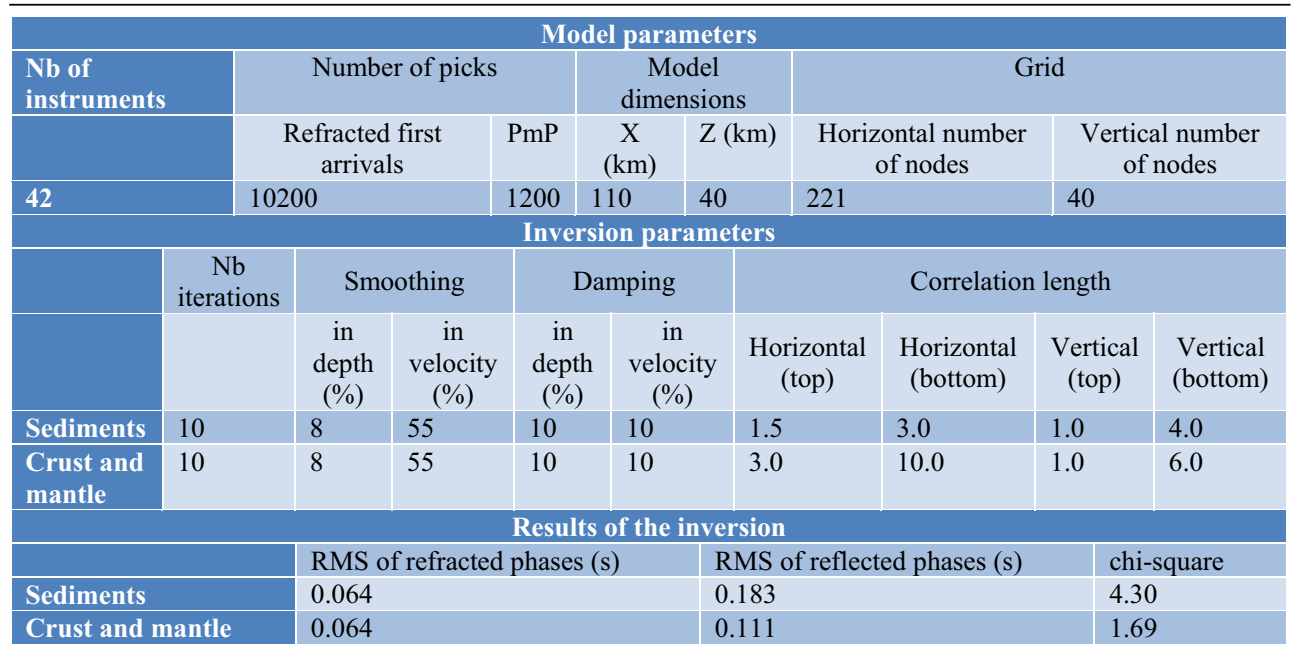

as a measure of model uncertainties. The derivative weight sum (DWS) which is the column sum vector of the velocity kernel provides information on the linear sensitivity of the inversion (Fig. $5 \mathrm{c}$; Korenaga et al. 2000).

The velocity uncertainties are generally lower than $0.2 \mathrm{~km} \mathrm{~s}^{-1}$, except on-land due to the lack of crossing rays and a low DWS, and locally in the lower crust between km-40 and 50. In this latter case there is possibly a trade-off between the Moho depth and the velocity in the lower crust.

The Moho depth is well constrained between km- 0 and km-20 $(9.6 \pm 0.34 \mathrm{~km})$ and between km-45 and km-55 (uncertainty of $\pm 0.45 \mathrm{~km}$ ) where it is deepening with an angle of up to $45^{\circ}$ (Fig. 5).

\subsection{Model resolution analysis}

Checkerboard is a conventional procedure to investigate the resolving power of the data set. To perform checkerboard tests, synthetic traveltimes are computed in a perturbed velocity model consisting of a lateral alternating squared pattern added to our final model. The resolution of our final model is evaluated by the capacity of the inversion to recover the perturbation pattern using our final velocity model as the starting model (Zelt 1998; Zelt et al. 2004). In order to obtain a good cartography of vertical resolution in our final model, we adapted and applied the method developed by Zelt (1998) for a 3-D tomography to our 2-D data set. We computed 40 checkerboard models with velocity anomalies ranging from $3 \times 3 \mathrm{~km}^{2}$ to $20 \times 20 \mathrm{~km}^{2}$ and amplitude of \pm 6 per cent. The results were compiled to obtain the ability of the data to resolve features of a given size according to depth (Fig. 6). In the first kilometres of the model, the vertical resolution is as low as $3 \mathrm{~km}$ showing that we indeed resolve some of the salt diapirs (Fig. 4a). Above $10 \mathrm{~km}$ depth and below the OBS line, we have a better resolution than $7-8 \mathrm{~km}$. A resolution of less than $15 \mathrm{~km}$ is obtained for the deepest point of ray penetration below the OBS line and for distance along the profile higher than $80 \mathrm{~km}$ due to a lack of ray crossing for the two isolated land stations.

\subsection{Seismic velocity structure}

The mean velocity model obtained from the Monte Carlo simulation (Fig. 5a) does not differ significantly from the best model (Fig. 4a) except it is smoother, especially in the sedimentary cover (velocity variation related to salt diapirs are almost faded away in the mean velocity model). Throughout the rest of this paper we will use the best velocity model obtained by the layer stripping approach (Figs $4 \mathrm{a}$ and $7 \mathrm{a}$ ). It exhibits a strong variation of the crustal velocity structure between the deep basin (km-0-42), where the seismic velocity reaches $6.7 \mathrm{~km} \mathrm{~s}^{-1}$ at $9 \mathrm{~km}$ depth, at the base of the crust, and the margin (km-55-90) where a similar velocity is reached at $\sim 15 \mathrm{~km}$ depth. In order to discuss the nature of the crust, we compare the velocity-depth curves extracted at different locations in our final model to reference velocity-depth curves for the oceanic crust (White et al. 1992) and for the continental crust (Christensen \& Mooney 1995; Figs 7b-d). Based on this analysis, three domains can be defined: the oceanic domain, the continental margin and the OCT zone.

\subsubsection{The oceanic domain}

This area is characterized by a relatively flat bathymetry $(\sim 2700 \mathrm{~m})$ from OBS19 towards the northern end of the profile (km-0-42; Figs 2 and 7a).

Along the coincident, time-migrated MCS profile (Fig. 8) the bottom of the sedimentary pile is an energetic seismic reflector located between 5.2 (at the northwestern end of the profile) and 5.8 stwt (at km-40) and is located at a depth of 6-7 km in our velocity model (Figs $4 \mathrm{a}$ and $7 \mathrm{a}$ ). Consequently the sedimentary cover is 3.3$4.3-\mathrm{km}$-thick with seismic velocities up to $4.8 \mathrm{~km} \mathrm{~s}^{-1}$ at its base. These high velocities are consistent with the presence of Messinian salt layers known throughout the Algerian Basin (Lofi et al. 2011). The $3.0 \mathrm{~km} \mathrm{~s}^{-1}$ isovelocity contours outline the geometry of salt diapirs (Figs 4a and 8).

Below this reflector, velocity-depth curves for the igneous crust fit within the envelope defined for the oceanic crust (White et al. 1992) but, at the same depth, its average velocity is higher than the average oceanic velocity (Fig. 7b). Only 2 OBS sections show clear PmP arrivals (e.g. OBS 27 in Figs 3 and 4a), whose traveltimes inversion defines the Moho at $10 \pm 0.5 \mathrm{~km}$ (Figs 4-5).

Although wide-angle reflection (PmP) from the Moho are sparse, weak near-vertical reflections appear from place to place, between 6.8 and 7.0 stwt, along MCS profile Spi02 (Fig. 8), and a clear reflective band appears along MCS profile $\mathrm{P} 4$, an industrial profile located near profile Spi02, between 6.5 and 7.0 stwt (Fig. 9). 

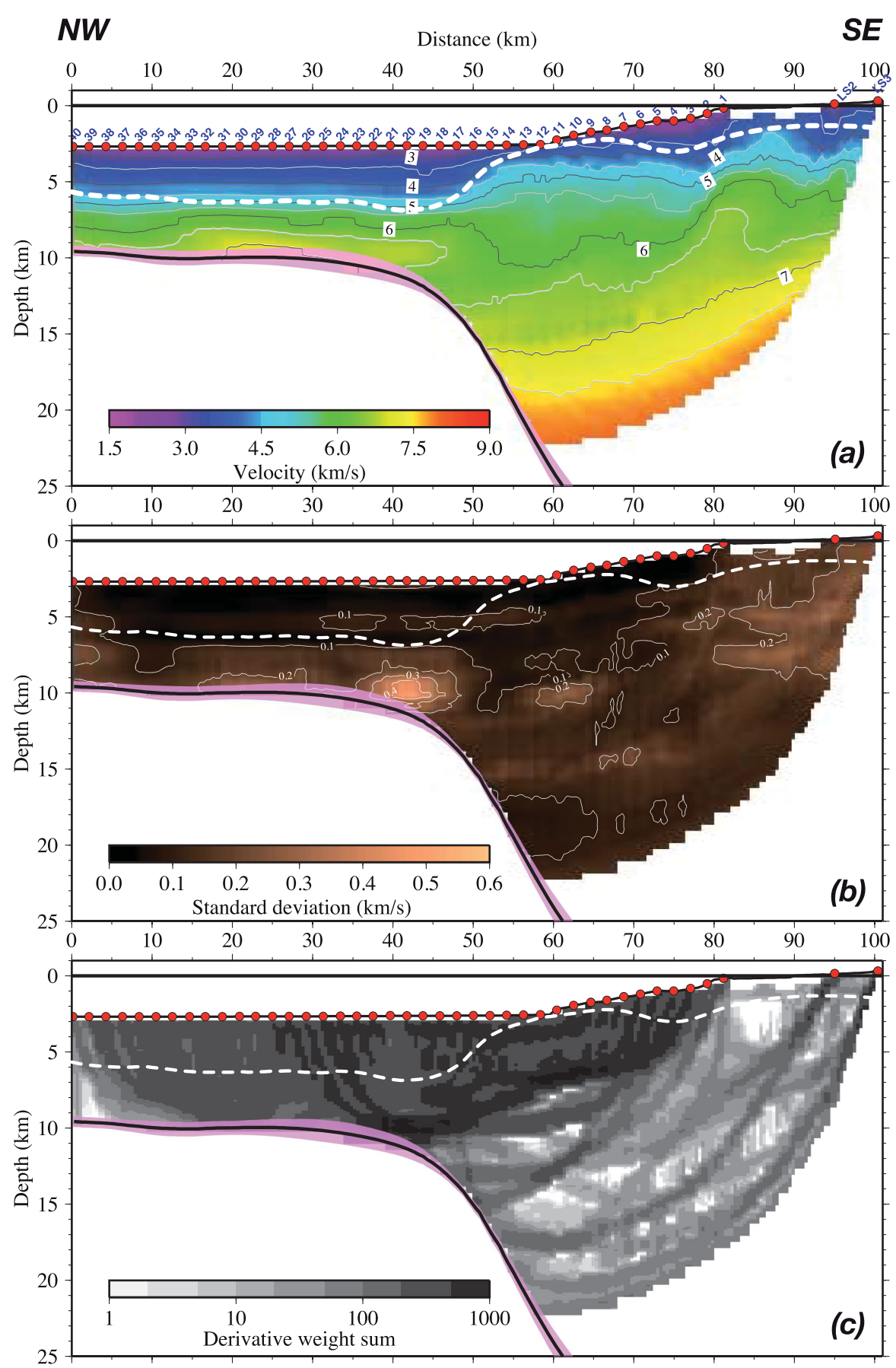

Figure 5. Result of the Monte Carlo simulation. (a) Mean velocity model and mean location of the Moho (thick black line) obtained by averaging the 100 final models resulting from the Monte Carlo simulation. (b) Final standard deviation values for the P seismic velocity and the Moho geometry (pink band), as a result of the statistical uncertainty analysis. (c) Derivative weight sum (DWS) values of the above tomographic model. Red circles display the location of the OBSs, OBHs and land stations used in this work. Numbers in blue refer to seismometers. The white dashed line indicates the location of the top of the acoustic basement. The mantle is not included in this simulation.

These differences are possibly frequency dependent: the reflections are weak along Spi02 (peak frequency of $20 \mathrm{~Hz}$ ) whereas they are stronger along profile L3 (peak frequency of $40 \mathrm{~Hz}$; Figs 8 and 9). At wide-angle, the Moho may be poorly reflective because the peak frequency is as low as $8 \mathrm{~Hz}$ for the wide-angle seismic data but also possibly because of poor signal-to-noise ratio on several OBS sections (Fig. S1). Nevertheless, the near vertical reflections ob- served on MCS lines correlate well with the Moho inferred from the wide-angle reflections identified on OBS40 and OBS27 record sections (Figs 3, 4a and 8) and likely represent reflections from the oceanic Moho. To the south, PmP phases recorded by OBS located on the margin (Fig. 3) constrain the Moho depth to $\sim 10 \mathrm{~km}$ at km40 (Fig. 4a) which is consistent laterally with our interpretation. We chose to model the oceanic Moho as a first order discontinuity 


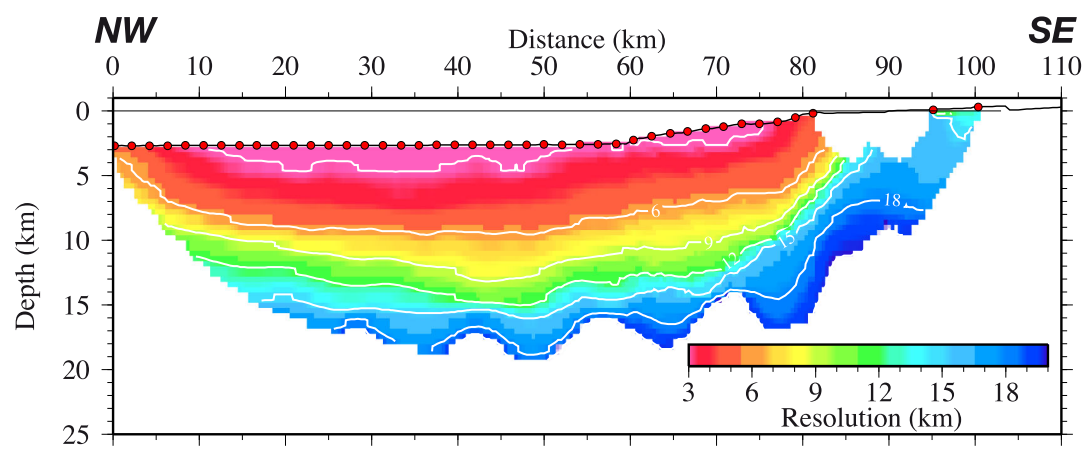

Figure 6. Resolution of the first arrival tomographic model. Eight types of checkerboard models were calculated for each velocity anomaly size $\left(3 \times 3 \mathrm{~km}^{2}\right.$, $6 \times 6 \mathrm{~km}^{2}, 10 \times 10 \mathrm{~km}^{2}, 15 \times 15 \mathrm{~km}^{2}$ and $20 \times 20 \mathrm{~km}^{2}$ ), with the pattern being spatially shifted and rotated by $45^{\circ}$ and the polarity of anomalies reversed. The semblance between the exact and recovered checkerboard is then calculated (Zelt 1998) for each checkerboard model and an average semblance for each anomaly size is derived. Part of the model with semblance higher than 0.7 are considered well resolved. Finally an interpolation is made to estimate at each node of the model, the anomaly size that will give a semblance higher or equal to 0.7 .

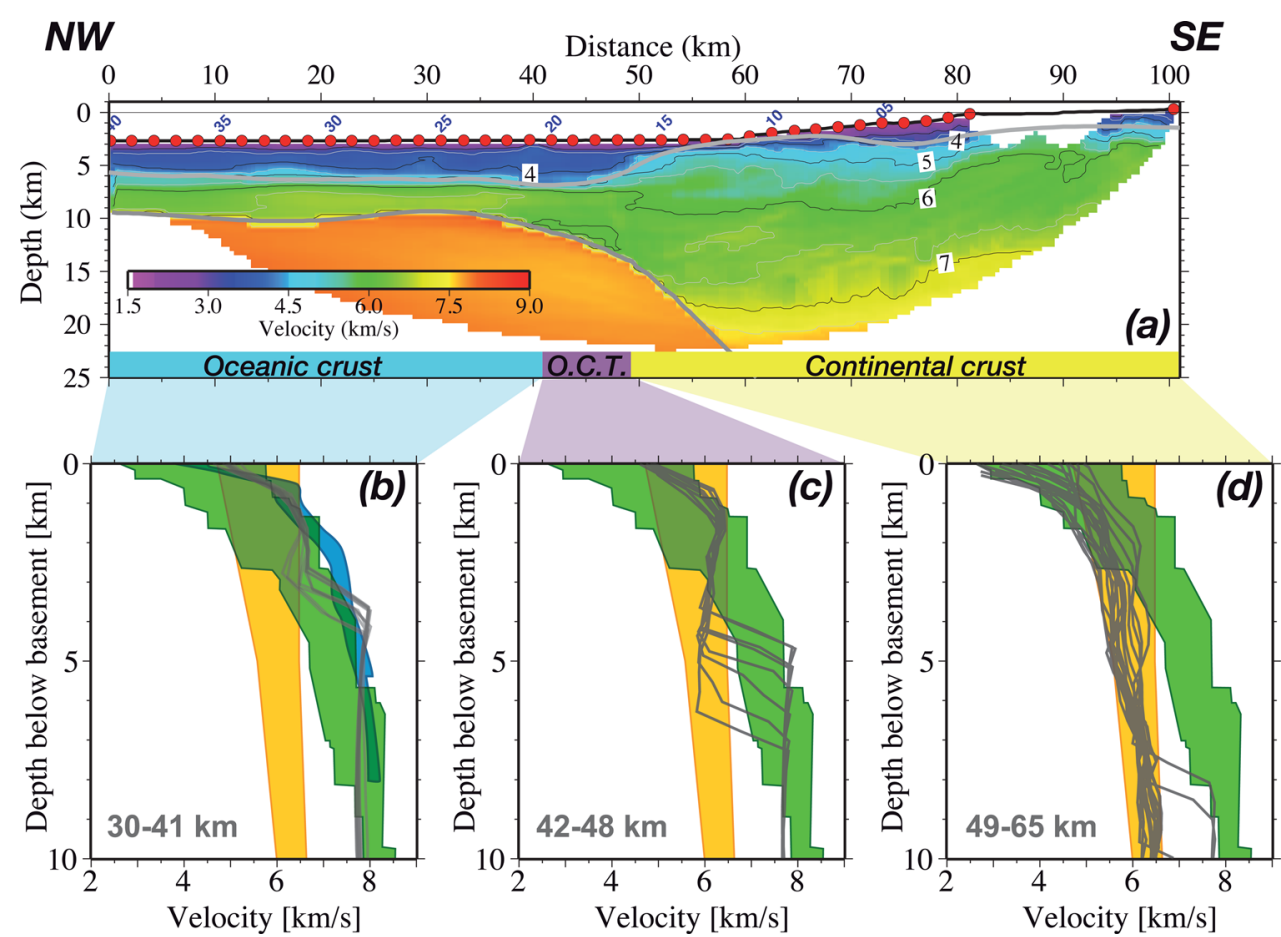

Figure 7. Interpretation of the velocity model. (a) Final velocity-depth model resulting from the traveltime inversion (same as in Fig. 4a) with no vertical exaggeration. OBS and land station LS locations are indicated by red circles, isovelocity contours are represented every $0.5 \mathrm{~km} \mathrm{~s}^{-1}$ and labelled every $1 \mathrm{~km} \mathrm{~s}^{-1}$. Thick grey lines represent the top of the acoustic basement, and the Moho discontinuity. OCT, ocean-continent transition. The 1-D velocity-depth profiles below the top of the basement were extracted at $1 \mathrm{~km}$ interval along the velocity model at distances of (b) $30-41 \mathrm{~km}$ (c) $42-48 \mathrm{~km}$ and (d) $49-65 \mathrm{~km}$. The yellow area represents a velocity compilation for extended continental crust extracted from (Christensen \& Mooney 1995), the light green area represents a velocity compilation for Atlantic oceanic crust from (White et al. 1992) and the blue area a compilation of exhumed mantle regions offshore West Iberia (Sallarès et al. 2013b).

but it is likely highly variable along the profile. In some place, the apparent lack of PmP and the reflectivity observed at normal incidence suggest the crust to mantle transition is smooth with thin embedded layers.

As first arrival Pn traveltimes are observed only on land stations and on OBS1 record sections (Fig. 3), the velocity in the upper mantle cannot be determined accurately but it is probably rather high ( $8.6 \mathrm{~km} \mathrm{~s}^{-1}$ in average).

These observations support a Moho depth of 9-10 km beneath the oceanic basin, which leads to a thickness of the igneous crust as low as $3-4 \mathrm{~km}$. In the two upper kilometres of the crust, seismic velocities range from 5.0 to $6.5 \mathrm{~km} \mathrm{~s}^{-1}$, and the vertical velocity gradient from $1.9 \mathrm{~km} \mathrm{~s}^{-1} \mathrm{~km}^{-1}$ at the top to $0.4 \mathrm{~km} \mathrm{~s}^{-1} \mathrm{~km}^{-1}$ at the bottom. The lower crust is with is $1-2 \mathrm{~km}$ thick with velocities from 6.5 to $6.8 \mathrm{~km} \mathrm{~s}^{-1}$ (Fig. $7 \mathrm{~b}$ ).

\subsubsection{The continental margin domain}

In this domain, the thickness of the sedimentary cover ranges from $\sim 0$ (at $60 \mathrm{~km}$ near the outer edge of the continental slope) to $3 \mathrm{~km}$ thick with seismic velocities reaching $4.0 \mathrm{~km} \mathrm{~s}^{-1}$ at its base 


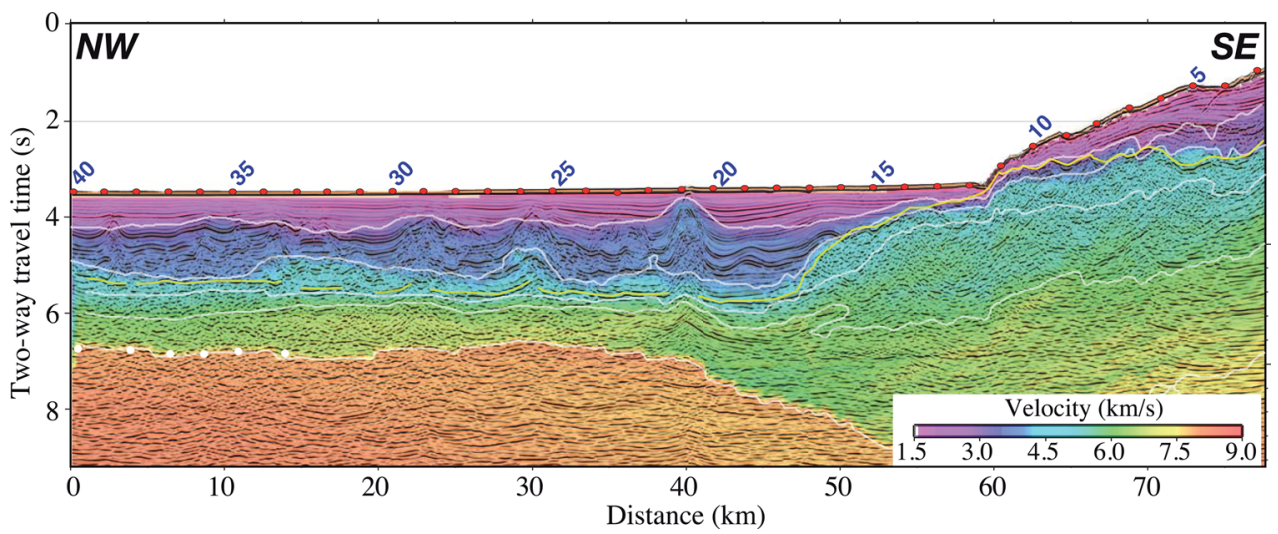

Figure 8. Time migrated section Spi02 superimposed on the final velocity model (Fig. 4a) converted in two way time. OBS locations are indicated by red circles. The yellow line indicates the top of the acoustic basement reflector interpreted on the MCS data. The light white lines are velocity contours 3.0, 4.0, $5.0,6.0$ and $7.0 \mathrm{~km} \mathrm{~s}^{-1}$. The sharp velocity contrast at the base of the crust coincides with the weak reflections (highlighted by white dots) recorded at $\approx 6.8-7$ stwt which are interpreted as the Moho discontinuity.

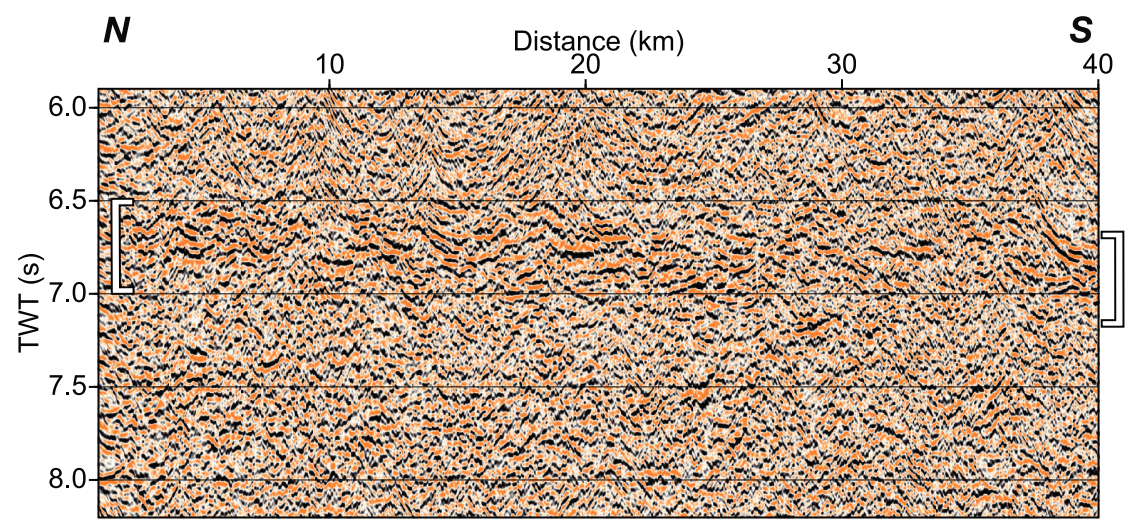

Figure 9. Time migrated seismic section P4 (see Fig. 2 for location). This line located in the vicinity of profile Spi02 clearly shows a reflective band between 6.5 and 7.0 stwt (indicated by brackets) which likely indicates the oceanic Moho at a time similar to that of the Moho reflections observed on profile Spi02 (Fig. 8).

which likely corresponds to recent detritic sediments (Domzig et al. 2006; Fig. 8).

From OBS-16 (km-50, Fig. 4b) to the end of the model onland, the velocity model exhibits a low vertical velocity gradient $\left(0.25 \mathrm{~km} \mathrm{~s}^{-1} \mathrm{~km}^{-1}\right.$ in average) that fits well within the range of thinned continental crust velocities (Fig. 7d; Christensen \& Mooney 1995). Continental crust extends beneath the continental slope and plateau. The Moho discontinuity, inverted as a reflector from PmP arrivals (Figs 4 and 5), dips rapidly towards the south from $\sim 15 \mathrm{~km}$ depth beneath OBS-16 (km-50) to more than $20 \mathrm{~km}$ towards the continent.

\subsubsection{The transition zone}

The OCT is located between OBSs 16-20 (km-50-42). This area is characterized by a $\sim 4-\mathrm{km}$-thick sedimentary sequence with seismic velocities of $4.5 \mathrm{~km} \mathrm{~s}^{-1}$ at its base (Figs $7 \mathrm{a}$ and 8).

This zone is characterized by 1-D velocity-depth curves which range between oceanic and continental velocities (Fig. 7c; White et al. 1992; Christensen \& Mooney 1995). The width of this region is less than $10 \mathrm{~km}$. It is characterized by a strong vertical velocity gradient in the upper crust $\left(0.6 \mathrm{~km} \mathrm{~s}^{-1} \mathrm{~km}^{-1}\right)$ and velocities in the range of continental velocities in the lower crust (Fig. 7d). The lower crust appears as a low velocity zone (Fig. 7c) but it is possibly an artefact as it coincides with high standard deviation in the Monte Carlo analysis (Fig. 5b).
In this area, OBSs recorded PmP reflections, allowing constraining the Moho discontinuity depth, which increases rapidly from 11 to $14 \mathrm{~km}$ with a dip of $\sim 27^{\circ}$. To the south, beneath the continental margin, the dip of the Moho has a value as high as $\sim 45^{\circ}$ (Figs $4 \mathrm{a}$ and 7a). The uncertainty on the Moho depth inferred from the Monte Carlo simulation is $\pm 0.45 \mathrm{~km}$ which leads to an uncertainty lower than $\pm 3^{\circ}$ on the Moho dip.

\section{INTERPRETATION OF SEISMIC REFLECTION LINES}

The study area is covered by several seismic surveys conducted by Sonatrach or in the framework of the scientific Algerian-French cooperation like the Maradja project (e.g. Domzig et al. 2006) or the SPIRAL project (Leprêtre et al. 2013; Medaouri et al. 2014). Two sections Spi02 and Spi04 are chosen to illustrate the Mostaganem general structure framework (Figs 10 and 11). Only large-scale features will be discussed here, concerning the OCT, the sedimentary cover of the deep basin and the major tectonic faults.

\subsection{Oceanic domain}

Based on the correlation between seismic profiles and various wells (Medaouri et al. 2012), it is possible to assign an age to the major sedimentary series observed throughout the area. These series 


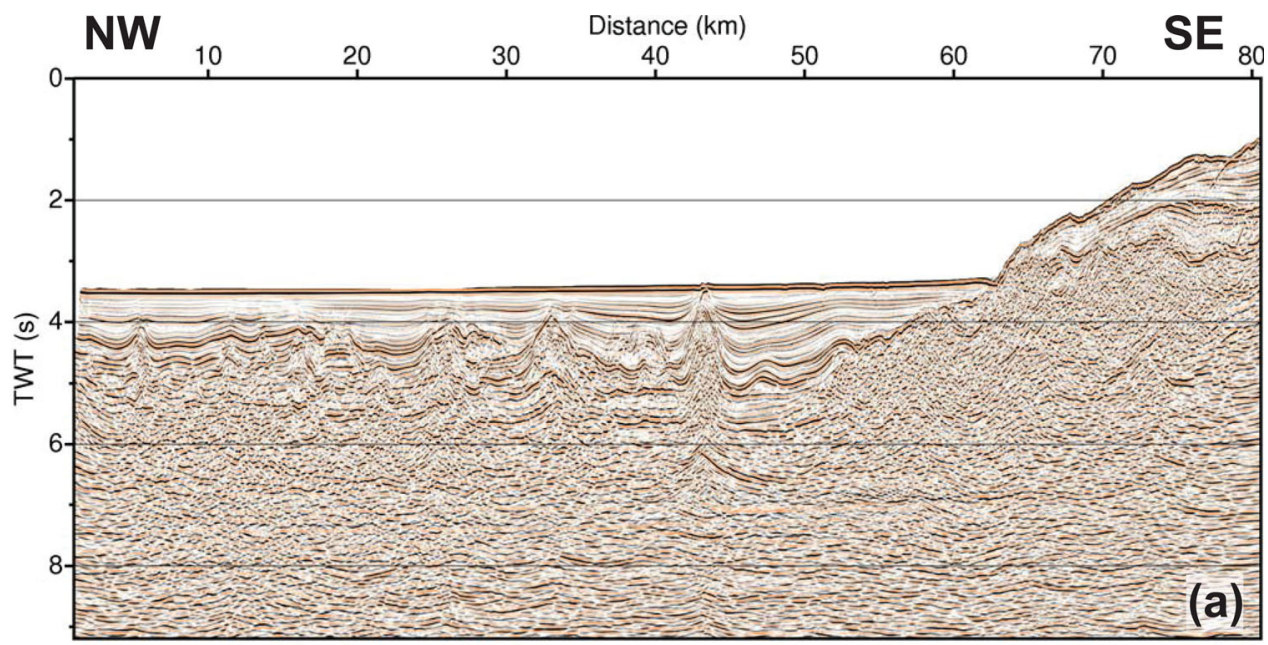

SPI02

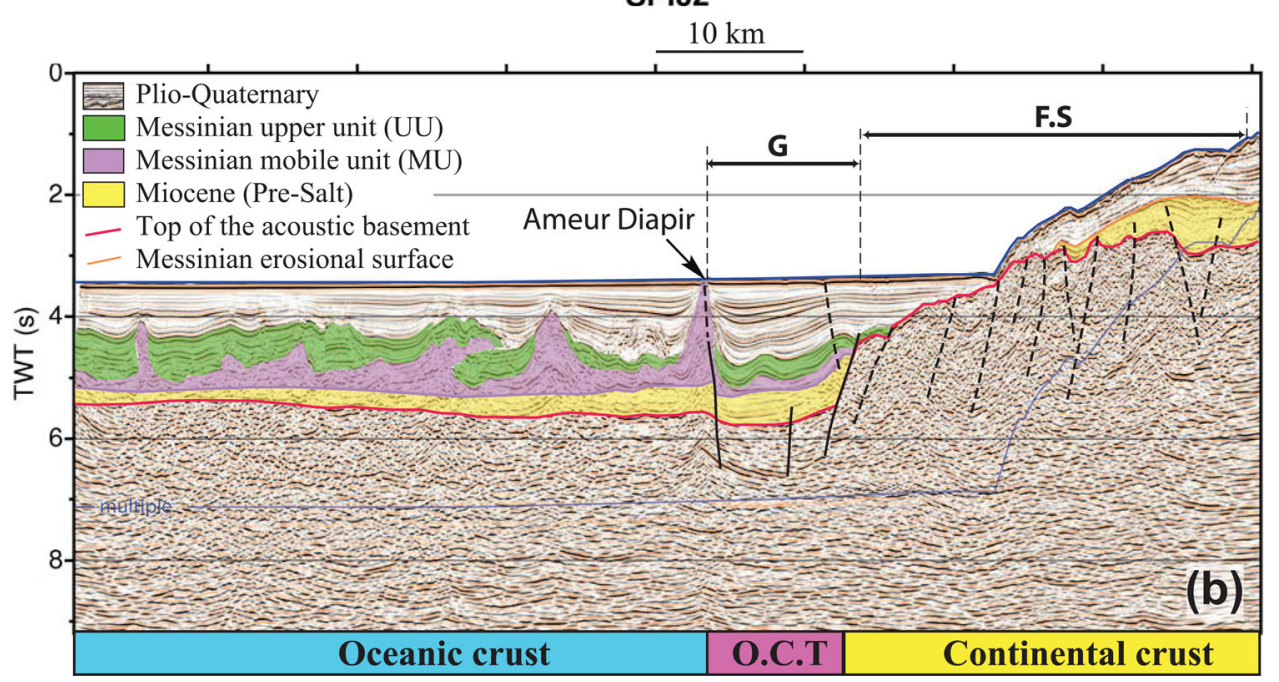

Figure 10. Time migrated MCS profile Spi02 (see location in Fig. 2). (a) Uninterpreted section. (b) Interpreted section showing major stratigraphic and structural units of the Algerian margin offshore Mostaganem. The limits of the oceanic crust, the continental crust and the OCT are from the tomographic inversion of coincident wide-angle seismic line. G: narrow asymmetric graben developed at the OCT. It is limited by two major vertical crustal faults, the northern one being underlined by a prominent salt structure (Ameur Diapir). FS: faults organized in a negative flower structure. The red line marked the top of the acoustic basement.

correspond to the succession classically observed in Western Mediterranean and previously described by several authors (Mauffret et al. 2004; Domzig et al. 2006). Along Spi02, Miocene sedimentary deposits lie directly on top of the oceanic basement (Fig. 10). The thickness of the evaporitic series associated to the Messinian salinity crisis, namely the mobile unit (MU) and the upper unit (UU) varies laterally as these layers are strongly affected by diapiric deformation (Lofi et al. 2011). Messinian diapirs crosscut the overburden Pliocene sedimentary series which are then discontinuous. These series are also affected by folds and faults related to the salt tectonics, in particular by small-offset faults at the top of diapirs. These deformations are sealed by the upper Quaternary deposits, supporting a diapiric tectonic phase ranging from Pliocene to mid-Quaternary, except for the southern diapirs, such as the one observed at km-43 on Spi02, which rises up to the surface (Fig. 10).

The southern limit of the oceanic domain identified from the tomographic model (km-42) coincides with the southernmost large diapir observed along line Spi02 (Figs 8-10). A similar large diapir is observed at km-72 along profile Spi04 (Fig. 11). This salt feature, named Ameur diapir, crosscuts the whole upper sedimentary deposits (Messinian upper evaporites, Pliocene and Quaternary series) and creates an escarpment on the seafloor which is visible as an almost continuous linear relief on the bathymetric map (Fig. 12). At depth under the salt ridge, the base of MU and the top of the basement are shifted of 0.1-0.5 stwt (km-43, Fig. 10 and km-73 Fig. 11), which can only be explained by crustal-scale faulting. It is known experimentally that viscous diapirs are observed to form above basement faults (e.g. Koyi et al. 1993). Consequently, we assume that this major salt ridge, which is observed on all the deep seismic lines, outlines a major crustal fault located at the boundary between the oceanic crust and the continental crust (Figs 10 and 11). The fault and/or the Ameur salt ridge affect the seafloor and have likely been active until recently.

\subsection{Continental margin and transition zone}

Along line Spi02, a narrow (10-km-wide) sedimentary basin developed on top of the OCT (labelled G, km-42-52, Fig. 10). Its northern flank is the major fault described before and marked by 

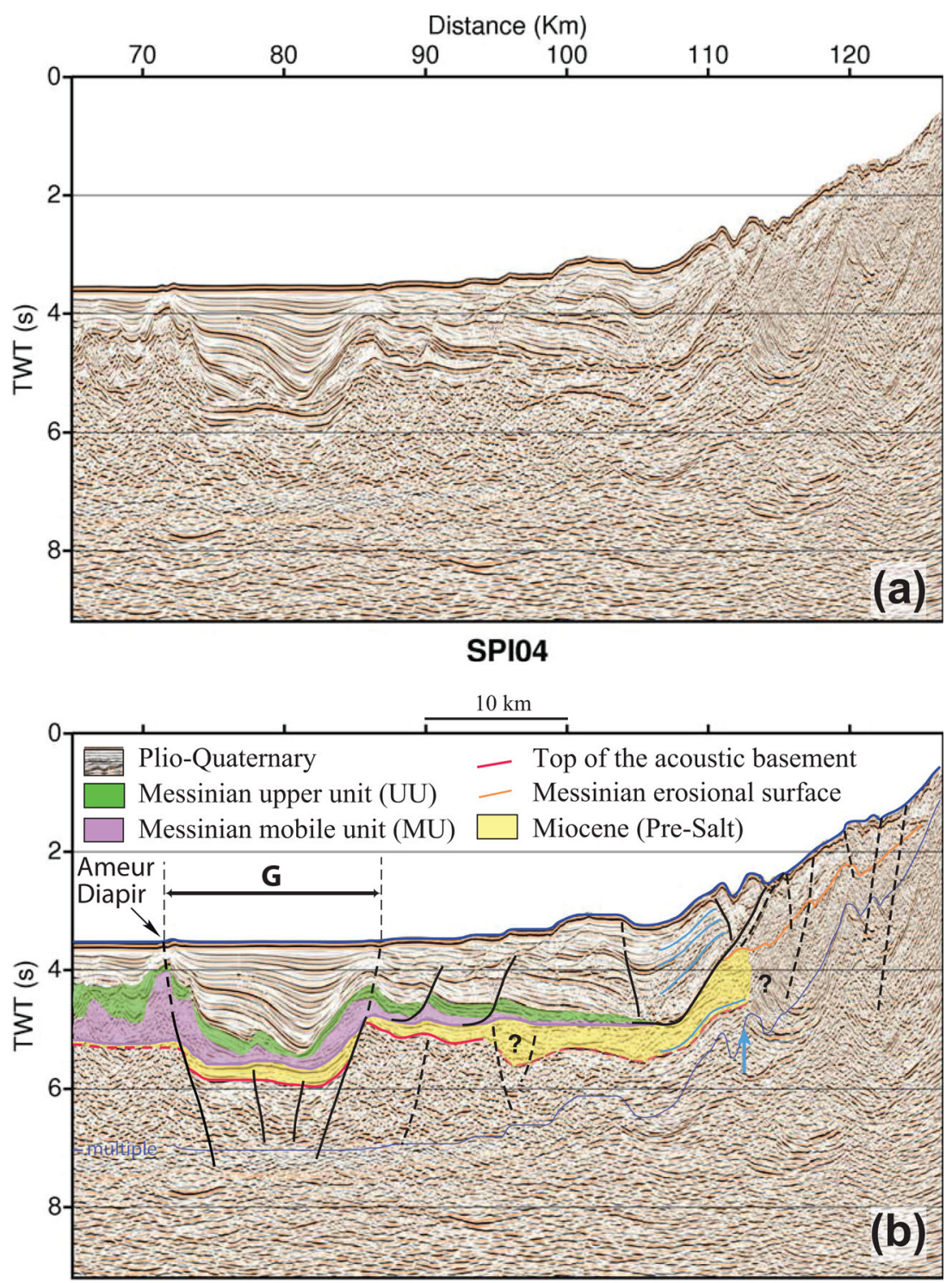

Figure 11. Same as Fig. 10 for MCS profile Spi04.

the Ameur salt ridge (Figs 8 and 10). This basin is filled with Miocene deposits, including the Messinian units MU and UU, and with a Plio-Quaternary sedimentary wedge which thickens towards the salt ridge. To the east, along line Spi04, a comparable basin is located in a similar position south of the oceanic domain (Fig. 11). Along this line, the basin is slightly wider ( $\sim 16 \mathrm{~km}$ wide $)$ and limited by two conjugate steep crustal faults along which the downward offset of the deep reflectors (base of MU and top of basement) is more important than westward. The sedimentary thickness is maximum in the basin (2.5 stwt), and the depocentre is located to its southern flank, with a Plio-Quaternary wedge thickened along the southern bounding fault. This indicates that the fault has been active until recently (Fig. 11).

This basin is observed on all the deep seismic lines, and forms a continuous narrow asymmetric basin (Fig. 12), which is most probably, as on line SPI02, located along the OCT of the margin. It is bounded by two steep conjugate crustal faults, the north one being outlined by the Ameur salt ridge (Fig. 12). This basin, which geometry evokes a negative flower structure, is likely associated to a strike-slip to transtensional deformation active from the Miocene to the Plio-Quaternary.

South of this basin, the continental crust of the margin appears tectonized, but the geometry of faulting is difficult to assess due to low resolution of the data and problematic seismic imagery under the steep slope. Along line Spi02, the rough topography of the top of the basement is in favour of a set of steep faults at mid-slope and probably higher under the margin, where an angular discordance exists in the basin perched on the upper slope (Fig. 10). This discordance corresponds to the Messinian erosional surface well known on Mediterranean margins (Lofi et al. 2011), indicating that deformation mainly occurred before the Plio-Quaternary. No recent deformation affects the foot of the slope, where the horizontal Plio-Quaternary layering on-laps the top of the acoustic basement. Northward, the OCT, which is very close to the margin, is characterized by the basin previously interpreted as associated to strike-slip deformation. This interpretation suggests that 


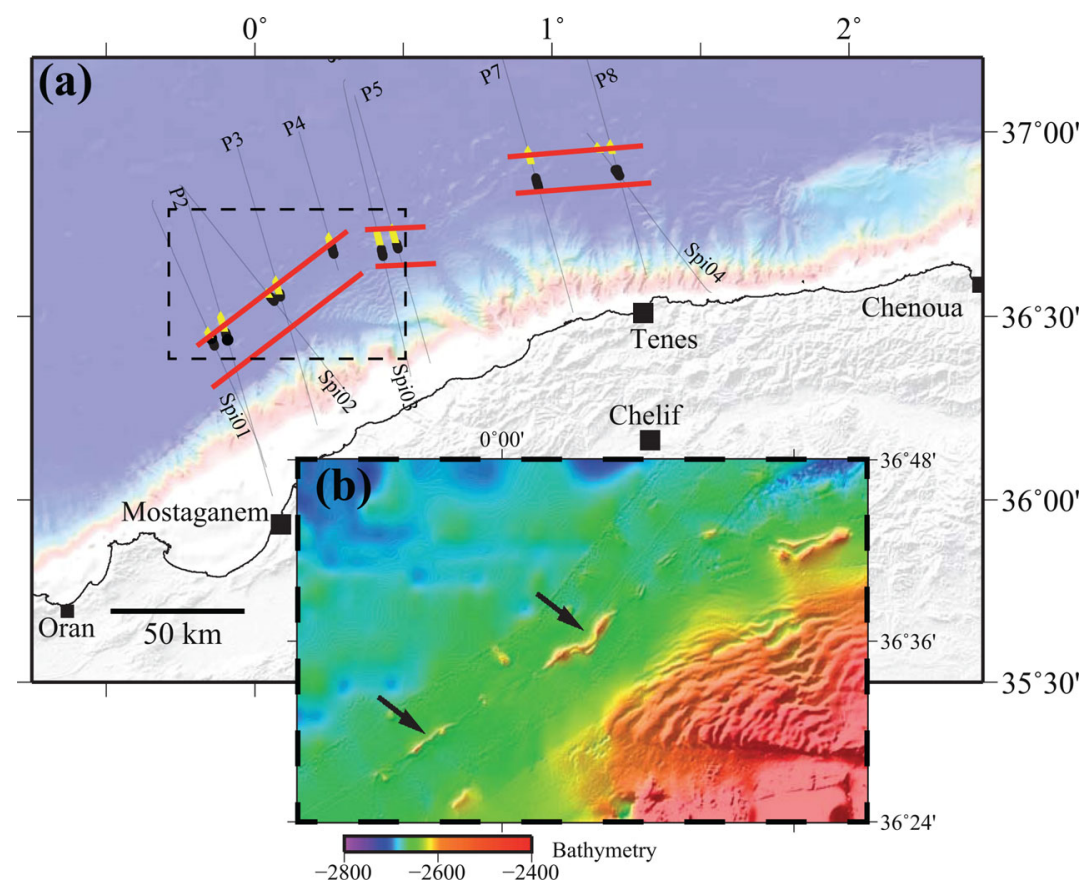

Figure 12. (a) Bathymetric and topographic map of the western Algerian margin (same as Fig. 2). The location of the graben identified on the MCS lines is outlined by the Ameur salt ridge (yellow dots) located above the northern bounding fault and the interpolated trace of the two major faults (red lines). Black squares indicate the basin depocentre. The SPIRAL and industrial MCS lines used to draw this sketch are indicated with thin black lines. The dash rectangle indicates the location of the enlargement in Fig. 12b. (b) Map showing the trace of the Ameur salt ridge in the bathymetry. It is straight and trending NE-SW parallel to the margin west of $0^{\circ} 18^{\prime}$ and it is trending $\mathrm{E}-\mathrm{W}$ east of this latitude.

strike-slip to transtensive deformation occurred both under the continental slope and at the OCT during Miocene, and that it likely went on during Plio-Quaternary at the OCT.

Along line Spi04, clear transtensional deformation occurs in the OCT basin which is farther north, limiting a $\pm 20 \mathrm{~km}$ wide area zone of supposed thin continental crust at the foot of the margin (Fig. 11). South of the OCT, the visible deformation is dominated by salt tectonics and Plio-Quaternary tectonic inversion at the foot of the margin. The area of thinned continental crust is characterised by a plio-quaternary roll-over basin typical of salt tectonics (e.g. Brun \& Fort 2004), with listric normal faults rooted in the MU acting as a decollement level. The lack of clear vertical offset of the base of MU suggests that only salt tectonics occurred in this area since Messinian. On the other hand, the sedimentary cover at the foot of the margin is marked by an upward curvature of the Miocene to Plio-Quaternary series against the northern flank of a deep antiform (Fig. 11). This peculiar geometry, which reveals an uplift of the slope relative to the deep basin, is most probably associated to the Plio-Quaternary tectonic inversion of the margin, as described eastward along the margin (Déverchère et al. 2005; Beslier et al. 2013; Leprêtre et al. 2013). Inversion-related structures are clearly expressed on the seismic lines at both ends of the study area, offshore Tenes and Oran, and not in-between in the Mostaganem area (Fig. 2). Tectonic inversion may then also explain that deformation affects the Plio-Quaternary series on line Spi04, possibly by reactivating structures inherited from the complex evolution of the margin. This compressive overprinting, together with numerous multiple-related parasite diffractions under the slope, prevents the identification of earlier structures. However, the steep and narrow slope, comparable to the one on line Spi02, suggests that transtensive deformation may also have controlled the morphostructure of the margin in this area.

As a whole, the morphostructure of the margin and OCT basin on line Spi02 evokes a negative flower structure (Fig. 10), and sug- gests that strike-slip to transtensive deformation prevailed during the formation of the margin and at the OCT in Miocene, and possibly persisted during the Plio-Quaternary at the OCT. On Spi04, a transtensive deformation regime has also prevailed in the OCT basin and likely on the margin.

\section{DISCUSSION}

\subsection{Oceanic crust of the Algerian Basin}

According to Grevemeyer \& Ranero (2011), the thickness of the oceanic crust that formed next to the Balearic promontory (Fig. 1) is up to $10 \mathrm{~km}$ thick, thinning to $5-6 \mathrm{~km}$ further offshore. To the south, along our seismic line, the crust is even thinner, decreasing from $4 \mathrm{~km}$ at the northwestern termination of the profile to $\sim 3 \mathrm{~km}$ near the transition zone (Figs $4 a$ and $7 a$ ).

Offshore Tipaza (west of Algiers at longitude 2.5 , Fig. 1), east of our study area, the Algerian Basin exhibits a $5.5-\mathrm{km}$ thick oceanic crust with a typical Layer 2/Layer 3 thickness ratio ( $\sim 1.5 \mathrm{~km} / \sim 4.0 \mathrm{~km}$; Leprêtre et al. 2013 ) suggesting that in this area the oceanic crust was emplaced in normal conditions (White et al. 1992).

The velocity structure of the oceanic crust offshore Mostaganem presents, for similar depth, a higher average seismic velocities than standard oceanic crust even if it still fits within the bounds defined for the oceanic crust (White et al. 1992; Fig. 7). It also presents some similarities with the velocity structure observed in the Iberian abyssal plain, to the foot of the continental slope (Sallarès et al. 2013b), which is interpreted as serpentinized upper-mantle outcropping beneath the sedimentary cover (e.g. Boillot et al. 1989). In both case, seismic velocities are higher compared to standard oceanic crust and the Moho is poorly reflective at wide-angle. 
Nevertheless the seismic structure of the exhumed mantle of the Gorringe bank exhibits a much more higher vertical velocity gradient in the upper layer $\left(\sim 2.5 \mathrm{~km} \mathrm{~s}^{-1} \mathrm{~km}^{-1}\right)$ and higher seismic velocities in the lower layer $\left(7.3-7.8 \mathrm{~km} \mathrm{~s}^{-1}\right.$; Sallarès et al. 2013b) than observed along our profile (respectively, $1.9 \mathrm{~km} \mathrm{~s}^{-1} \mathrm{~km}^{-1}$ and $6.5-6.8 \mathrm{~km} \mathrm{~s}^{-1}$ ).

Offshore Mostaganem the Moho is mostly underlined by horizontal reflectivity observed at normal incidence (Figs 8 and 9). Similar subhorizontal reflectivity is described off the northern Nova Scotia rifted continental margin (eastern Canada) where it is interpreted as a serpentinization front (Funck 2004). In slow to ultraslow spreading environment, where tectonism is important, the magmatic crust is often discontinuous, the lower crust consists, at least partly, of serpentinized mantle and therefore the seismic Moho may correspond to the serpentinisation front (e.g. near the Mid-Atlantic Ridge, Canales et al. 2000; near the Southwest Indian Ridge, Muller et al. 2000; in the ophiolites of Western Alps, Debret et al. 2013). The seismic signature of the Moho support the presence of serpentines in the lower crust offshore Mostaganem. Nevertheless, the seismic velocity structure is akin to oceanic crust emplaced at slow spreading centre rather than exhumed upper mantle.

The emplacement of the Algerian Basin is poorly constrained because of the lack of a clear magnetic pattern (Schettino \& Turco 2006; Medaouri et al. 2014). Following the authors, it is partly related to the north to northwest dipping subduction of the Tethyan Ocean and to the westward migration of the Alborán domain (Mauffret et al. 2004; Schettino \& Turco 2006; Medaouri et al. 2014). Nevertheless, in a simplistic one-step EW opening of the Algerian Basin, the $350 \mathrm{~km}$ westward migration of the Alborán domain from $\sim 16$ to $5 \mathrm{Ma}$ is consistent with an opening rate of a few centimetres per year (Medaouri et al. 2014). At one extreme, if the $560-\mathrm{km}$-long strip of oceanic crust of the Algerian Basin was generated between 16 and $8 \mathrm{Ma}$, this lead to an average rate of $7 \mathrm{~cm} \mathrm{yr}^{-1}$ (Mauffret et al. 2004). The actual rate of accretion of the Algerian Basin is largely unknown, because spreading possibly occurred at different centres, but it probably ranges from slow to medium rate which is consistent with the average crustal thickness and the presence of serpentinized peridotites in the lower crust (Grevemeyer \& Ranero 2011; Leprêtre et al. 2013; this paper).

In back-arc basins, the structure of the oceanic crust is highly variable. The crust may be thicker in the vicinity of the volcanic island arc (e.g. in the Lau Basin, Dunn \& Martinez 2011; in the Tyrrhenian Basin, Prada et al. 2014) or thinner than in large oceanic basins. In this latter case it is interpreted as resulting from slow spreading rate axis and a low temperature upper mantle due to the subduction of the cold slab which cools down the upper mantle (e.g. Philippine sea and Parece Vela basins; Sclater et al. 1976; Louden 1980). In the Ligurian Basin, a backarc basin emplaced in the same context as the Algerian Basin between the Gulf of Lion and the Sardinia margins the oceanic crust is $5 \mathrm{~km}$ thick (Pascal et al. 1993; Contrucci et al. 2001; Gailler et al. 2009). In this case, the authors also suggest that this anomalous thickness is related to low mantle temperature beneath the accretion axis during the emplacement of this backarc basin.

In the vicinity of fracture zones and magma-poor continental margins, the oceanic crustal thickness can be as low as $3.0-4.0 \mathrm{~km}$ (White et al. 1992). Near fracture zones, the crust is characterized by the absence of a normal seismic Layer 3 which is otherwise extremely homogeneous throughout the world's oceans (White et al. 1992; Detrick et al. 1993). The lack of a normal thickness Layer 3 indicates that magmatic accretion is focused at segment centres and melt is delivered to segment ends mostly by lateral migration of magma (Minshull et al. 2006). Similarly, the oceanic crust emplaced in the vicinity of transform margins is usually thinner than the average. For instance, offshore the Ghana-Ivory Coast transform margin, the oceanic crust is $3-4 \mathrm{~km}$ thick (Sage et al. 2000), whereas the conjugate margin (namely, the French Guiana-Northeast Brazil margin) shows a 3.3-5.7 km oceanic crustal thickness (Greenroyd et al. 2008). The thin oceanic crust emplaced near transform margins is tentatively related to (1) the cold edge effect of the adjacent continental lithosphere on the oceanic spreading centre, (2) the accretion at the end of a ridge segment away from the maximum magma supply (located at the centre of the ridge segment) and/or (3) an efficient cooling of the oceanic lithosphere favoured by hydrothermal circulation in the highly fractured OCT (Sage et al. 2000).

The crust of the Algerian Basin varies from normal oceanic crust (Grevemeyer \& Ranero 2011) south of Balearic Islands to thin crust with a thin Layer 3 of serpentinized peridotites offshore Mostaganem (Fig. 7a). This suggests that the crust of the southern edge of the Algerian Basin was emplaced in a cold environment (with less partial melting) possibly away from the source of magma (i.e. the centre of the spreading axis segment) and/or nearby the cold continental lithosphere of the Algerian margin.

\subsection{Tectonic origin of the continental margin of western Algeria}

\subsubsection{Variations along the Algerian margin}

The western Algerian margin is trending N65-N70 ${ }^{\circ} \mathrm{E}$ west of the longitude of $1^{\circ}$ (near Tenes) and then $\mathrm{N} 85^{\circ}$ eastward. West of Tenes, it is characterized by a narrow continental shelf ( $<10 \mathrm{~km}$ wide) and a steep continental slope (Fig. 2). The bathymetry increases from $700 \mathrm{~m}$ depth upslope to $2700 \mathrm{~m}$ in the abyssal plain over a distance of $8 \mathrm{~km}$, leading to a slope up to 25 per cent $\left(\sim 14^{\circ}\right.$; Fig. 2 ; Domzig et al. 2006).

Further east, offshore Tipaza, the OCT occurs across a less than $10 \mathrm{~km}$ transition zone comparable to that modelled in this paper (Fig. 7; Leprêtre et al. 2011, 2013). Nevertheless, the Moho deepening is 8 -fold steeper in the Mostaganem area $\left(\sim 45^{\circ}\right.$ dip) than offshore Tipaza $\left(\sim 6^{\circ}\right.$; Leprêtre et al. 2011,2013$)$. The Moho reaches $\sim 25 \mathrm{~km}$ at $\sim 20 \mathrm{~km}$ offshore from the coastline along our profile (Fig. 4) whereas at a similar position relative to the coastline it is only at $\sim 17 \mathrm{~km}$ depth offshore Tipaza (Leprêtre et al. 2013).

Along line Spi02, the transition zone between the continental and the oceanic crust coincides with a narrow graben (labelled $G$ in Figs 10 and 11) which is observed along all the seismic profiles shot across the margin between Mostaganem and Tenes (Fig. 12).

The Algerian margin off Tipaza exhibits evidence for an early stage of rifting and crustal thinning (Lepretre et al. 2013) which is missing offshore Mostaganem, where the thin oceanic crust, the narrow OCT, the lack of thinned continental crust beneath the margin (i.e. the sharp Moho transition), and the flower structure described earlier support a pure strike-slip type margin.

\subsubsection{Comparison with strike-slip margins}

The western Algerian margin coincides with the trail of the southern edge of the Gibraltar subduction (see dotted line in Fig. 1), and lies above the detached slab inferred from global tomography (Spakman \& Wortel 2004). The most recent tectonic reconstruction and 3-D numerical modelling of slab rollback support the E-W opening of the Algerian Basin and the lithosphere tearing 
along the north Algerian margin as a result of the rollback of the Gibraltar slab (Chertova et al. 2014; van Hinsbergen et al. 2014). This Subduction-Transform Edge Propagator, or STEP fault system was already proposed by different authors based on tomography of the upper mantle and kinematic reconstruction (Lonergan \& White 1997; Govers \& Wortel 2005; Chertova et al. 2014; van Hinsbergen et al. 2014).

STEPs are basically different from transform plate boundaries, although they may sometimes mimic their kinematic behaviour. Here the overriding plate trails the trench during rollback but because of internal extension of the Alboran block and opening of the Algerian Basin the amount of strike-slip along the STEP fault is highly variable. The translation of the overriding plate also means that oceanic crust did not form adjacent to the continent it now sits next to, so it may or may not have a transform cooling effect.

Most transform margins, like the Ghana-Ivory Coast transform margin and its conjugate margin of the French Guiana-Northeast Brazil margin, exhibit a narrow OCT zone (Edwards et al. 1997; Sage et al. 1997, 2000) or even no transition zone at all (Greenroyd et al. 2008). Based on seismic velocities, the transition zone is defined as the zone where seismic velocities can have values between those observed in the continental and the oceanic crust. The seismic velocities could be related either to continental crust intruded by oceanic material during the early emplacement of the oceanic crust or to a tectonic mélange of oceanic and continental rocks during the strike-slip movement along this major fault (Eberhart-Phillips et al. 1995).

This zone is also characterized by a sharp thinning of the continental crust (i.e. a very steep Moho and continental slope). Many transform margins share other characteristics, such as high marginal ridges, $1-3 \mathrm{~km}$ over the seafloor, developed along the continental side of the margin and possibly related to the heating by the accretion ridge (Bird 2001) or to erosion of the basement (Basile \& Allemand 2002). Such a ridge is not observed along the Algerian margin, because the continental margin was not affected by the thermal effect of the oceanic spreading center. The Alborán domain and the western part of the Algerian Basin were likely translated southwestward relative to the continent. Accordingly, the oceanic crust adjacent to the Mostaganem segment of the margin likely formed further east (Mauffret et al. 2004).

Major STEP faults are known, for example at the southern end of the Lesser Antilles subduction zone, across the boundary between the South American and Caribbean plates (Govers \& Wortel 2005). There, a $33 \mathrm{~km}$ wide, near-vertical strike-slip system, crosscuts the whole lithosphere and coincides with a steep, $16 \mathrm{~km}$ high transition in Moho depth (Clark et al. 2008a,b). Another example is the southwestern boundary of the Tyrrhenian-Calabrian subduction system marked by a major vertical fault, with strike-slip movement that accommodates in the upper plate the rollback of the Calabrian subduction zone and separates oceanic and thinned continental crust (Gallais et al. 2013). Those two examples show that the STEP fault propagates through the inherited potential weakness zones, such as the OCT of the Ionian Basin, East of Sicily (Frizon de Lamotte et al. 2011; Gallais et al. 2011), or the transition between a remnant island arc and continental South America in the case of the South American-Caribbean STEP fault (Clark et al. 2008a).

The continental margin of western Algeria presents many similarities with other STEP fault margins. The strike-slip motion occurred partly along the narrow basin located above the OCT zone and observed all along the margin. West of Tenes, the morphostructure of the margin under the continental slope evokes a negative flowerstructure (labelled FS, Fig. 10) comparable to the ones described across major strike-slip faults like the Yusuf fault (Alvarez-Marrón 1999; Medaouri et al. 2014), the French Guiana transform margin (Greenroyd et al. 2008) or across the North Anatolian fault (Beyhan et al. 2010). This strike-slip fault system is most likely part of the STEP fault system, together with the OCT basin.

East of Tenes, the basin trending $\mathrm{N} 88^{\circ}$ is still parallel to the margin, but it is located $20 \mathrm{~km}$ north of the outer edge of the continental slope, supporting the presence of thinned continental crust between the continental slope and the basin. Evidence of compressional reactivation clearly exists at least at the foot of the continental slope. These features are common with the segment located eastward, offshore Tipaza (Leprêtre et al. 2013), where a complex multiphased tectonic history is suspected: (1) an early stage of rifting and thinning of the continental crust, (2) the accretion of the forearc domain (the so-called $\mathrm{AlKaPeCa}$ domain) to the African margin, (3) the westward migration of the Alborán domain along the STEP fault and (4) a recent Plio-Quaternary compressional reactivation of the margin. The morphostructure of the margin on line Spi04 suggests that this segment extends up to the change in direction of the margin at the longitude of $1^{\circ}$ (Fig. 12). The transtensional deformation evidenced in the OCT basin may be the trace of the STEP system offshore Tenes. The continuity of the steep slope may suggest that the margin is also part of it in this area, but further studies are needed to discuss this hypothesis and the relationships with the segment of the margin east of Tenes.

A striking feature of the Algerian margin in the study area is the presence and the continuity of the strike-slip basin at the OCT of the margin, in spite of a segmentation of the continental domain revealed by (1) a narrow transform-type structure westward of Tenes that widen eastward with the presence of continental crust at the foot of the margin and (2) the occurrence of recent tectonic inversion offshore Oran and Tenes but not in the Mostaganem area. This basin developed at the OCT is likely the trace of the STEP fault located at the southern edge of the Gibraltar subduction which crosscut the continental crust during the Early Miocene-to-Lower Tortonian westward migration of the Alborán block (Medaouri et al. 2012).

\section{CONCLUSIONS}

The final tomographic model, as well as available seismic reflection lines, reveals striking features in the deep structure of the margin west of Tenes, from north to south:

(1) The 4-km-thick oceanic crust, with velocities ranging from 4.8 to $6.8 \mathrm{~km} \mathrm{~s}^{-1}$, was likely emplaced in a cold environment or at a slow spreading ridge. We observe no evidence of exhumed serpentinized upper mantle as described along many extensional magma-poor continental margins but nevertheless the lower crust possibly consists partly of serpentinized peridotites. The basin is filled with a 3.3-km-thick sedimentary pile characterized by an intense diapiric activity of the Messinian salt layer.

(2) The sharp OCT, less than $10 \mathrm{~km}$ wide, coincides with a narrow, elongated, almost continuous basin imaged by multichannel seismic data.

(3) The slightly thinned continental crust coincident with an extremely rapid variation of the Moho depth imaged from 12 to $\sim 20 \mathrm{~km}$ with a dip up to $45^{\circ}$. The seafloor bathymetry is showing a steep continental slope $\left(\sim 14^{\circ}\right)$. Suspected faults along deep MCS lines do not show any large vertical displacements but rather appear as a flower structure. All these observations strongly support that the structure of the margin is primarily related to strike-slip motion with no extensional phase west of Tenes. 
(4) Some recent compressive deformations are observed east of Tenes whereas there is no evidence of such reactivation of the margin west of Tenes.

These results support the hypothesis that the margin offshore Mostaganem is not an extensional margin but rather a transform-type margin born as a response to the rollback and lateral tear of the narrow slab of the Gibraltar Subduction. The Subduction-Transform Edge Propagator (STEP) created a major shear zone located at the continental-ocean transition but possibly also affecting the edge of the continent.

\section{ACKNOWLEDGEMENTS}

This work is part of the Algerian-French SPIRAL program (Sismique Profonde et Investigation Régionale du Nord de l'Algérie) to study the deep structure of the Algerian Margin using wide-angle and multichannel seismic data. It is a cooperation between SONATRACH, the 'Direction Générale de la Recherche Scientifique et du Développement Technologique' (DGRSDT), the 'Centre de Recherche en Astronomie, Astrophysique et Géophysique' (CRAAG), the Institut Français de Recherche pour 1'Exploitation de la Mer (IFREMER), the Institut de Recherche pour le Développement (IRD), the Centre National de la Recherche Scientifique (CNRS), the Université Nice Sophia Antipolis (UNS), and the Université de Bretagne Occidentale (UBO). We thank the captain and the crew of the R/V L'Atalante and the technical team who operated the IFREMER and UBO OBS at sea. We are also indebted to the scientific team of the SPIRAL project and to Marc-André Gutscher for helpful discussions and comments on an early version of the manuscript. Reviews by Valenti Sallarès and Timothy Hentsock were greatly appreciated. We also benefit from fruitful discussions with M.J.R. Wortel about the structure of STEP faults. The GMT (Wessel \& Smith 1998) and Seismic Unix software package (Stockwell 1999) were used in the preparation of this paper.

\section{REFERENCES}

Acosta, J., Muñoz, A. \& Herranz, P., 2001. Geodynamics of the Emile Baudot escarpment and the Balearic Promontory, western Mediterranean, Mar. Pet. Geol., 18(3), 349-369.

Alvarez-Marrón, J., 1999. Pliocene to Holocene structure of the eastern Alboran Sea (western Mediterranean), in Proceedings of the Ocean Drilling Program, Scientific Results, College Station, TX, Vol. 161, pp. 345-355, eds Zahn, R., Comas, M.C. \& Klaus, A.

Auffret, Y., Pelleau, P., Klingelhoefer, F. \& Geli, L., 2004. MicrOBS: a new generation of ocean bottom seismometer, First Break, 22(7), 41-47.

Avedik, F., Renard, V., Allenou, J. \& Morvan, B., 1993. "Single bubble" air-gun array for deep exploration, Geophysics, 58(3), 366-382.

Basile, C. \& Allemand, P., 2002. Erosion and flexural uplift along transform faults, Geophys. J. Int., 151(2), 646-653.

Berkhout, A.J. \& Verschuur, D.J., 1997. Estimation of multiple scattering by iterative inversion, Part I: theoretical considerations, Geophysics, 62(5), 1586-1595.

Beslier, M.-O. et al., 2013. Tectonic Inversion of the Algerian Continental Margin off Great Kabylia (North Algeria) - insights from new MCS data (SPIRAL cruise), in Proceedings of the Fall Meeting, San Francisco, p. T21A-2529.

Beyhan, G., Selim, H.H. \& Özçiçek, B., 2010. Tectonics related to the North Anatolian Fault in the Sea of Marmara: evidence from seismic reflection data, Mar. geophys. Res., 30(4), 237-250.

Bird, D., 2001. Shear margins: continent-ocean transform and fracture zone boundaries, Leading Edge, 20(2), 150-159.
Boillot, G., Féraud, G., Recq, M. \& Girardeau, J., 1989. Undercrusting by serpentinite beneath rifted margins, Nature, 341(6242), 523-525.

Booth-Rea, G., Ranero, C.R., Martínez-Martínez, J.M. \& Grevemeyer, I., 2007. Crustal types and Tertiary tectonic evolution of the Alborán sea, western Mediterranean, Geochem. Geophys. Geosyst., 8(10), doi:10.1029/2007GC001639.

Bouillin, J.-P., 1986. Le "bassin maghrébin": une ancienne limite entre l'Europe et l'Afrique à l'ouest des Alpes, Bull. la Société Géologique Fr., 8(4), 547-558.

Bracène, R. \& Frizon de Lamotte, D., 2002. The origin of intraplate deformation in the Atlas system of western and central Algeria: from Jurassic rifting to Cenozoic-Quaternary inversion, Tectonophysics, 357, 207-226.

Brun, J.-P. \& Fort, X., 2004. Compressional salt tectonics (Angolan margin), Tectonophysics, 382(3-4), 129-150.

Camerlenghi, A., Accettella, D., Costa, S., Lastras, G., Acosta, J., Canals, M. \& Wardell, N., 2008. Morphogenesis of the SW Balearic continental slope and adjacent abyssal plain, Western Mediterranean Sea, Int. J. Earth Sci., 98(4), 735-750.

Canales, J.P., Detrick, R.S., Lin, J., Collins, J.A. \& Toomey, D.R., 2000. Crustal and upper mantle seismic structure beneath the rift mountains and across a nontransform offset at the Mid-Atlantic Ridge $\left(35^{\circ} \mathrm{N}\right)$, J. geophys. Res., 105(B2), 2699, doi:10.1029/1999JB900379.

Chalouan, A. \& Michard, A., 2004. The Alpine Rif Belt (Morocco): a case of mountain building in a subduction-subduction-transform Fault Triple Junction, Pure appl. Geophys., 161(3), 489-519.

Chertova, M.V., Spakman, W., Geenen, T., van den Bergm, A.P. \& van Hinsbergen, D.J.J., 2014. Underpinning tectonic reconstructions of the western Mediterranean region with dynamic slab evolution from 3-D numerical modeling, J. geophys. Res.: Solid Earth, 119(7), 5876-5902.

Christensen, N.I. \& Mooney, W.D., 1995. Seismic velocity structure and composition of the continental crust: a global view, J. geophys. Res., 100(B6), 9761-9788

Clark, S.A., Zelt, C.A., Magnani, M.B. \& Levander, A., 2008 a. Characterizing the Caribbean-South American plate boundary at $64^{\circ} \mathrm{W}$ using wide-angle seismic data, J. geophys. Res., 113(B7), B07401, doi:10.1029/2007JB005329.

Clark, S.A., Sobiesiak, M., Zelt, C.A., Magnani, M.B., Miller, M.S., Bezada, M.J. \& Levander, A., 2008b. Identification and tectonic implications of a tear in the South American plate at the southern end of the Lesser Antilles, Geochem. Geophys. Geosyst., 9(11), doi:10.1029/2008GC002084.

Comas, M.C., García-Dueñas, V. \& Jurado, M.J., 1992. Neogene tectonic evolution of the Alboran Sea from MCS data, Geo-Marine Lett., 12(2-3), $157-164$.

Comas, M.C., Platt, J.P., Soto, J.I. \& Watts, A.B., 1999. 44. The origin and tectonic history of the Alboran Basin: insights from Leg 161 results, in Proceedings of the Ocean Drilling Program, Scientific Results, Vol. 161, pp. 555-580.

Contrucci, I., Nercessian, A., Béthoux, N., Mauffret, A. \& Pascal, G., 2001. A Ligurian (Western Mediterranean Sea) geophysical transect revisited, Geophys. J. Int., 146(1), 74-97.

Cope, M., 2003. Algerian licensing round may offer opportunity for exploration plays in deep offshore frontier, First Break, 21(July), 35-40.

Debret, B., Nicollet, C., Andreani, M., Schwartz, S. \& Godart, M., 2013. Three steps of serpentinization in an eclogitized oceanic serpentinization front (Lanzo Massif-Western Alps), J. Metamorph. Geol., 31(2), $165-186$.

Detrick, R.S., Harding, A., Kent, G. \& Orcutt, J., 1993. Seismic structure of the southern East Pacific Rise, Science (80-), 259(5094), 499-503.

Déverchère, J. et al., 2005. Active thrust faulting offshore Boumerdes, Algeria, and its relations to the $2003 \mathrm{Mw} 6.9$ earthquake, Geophys. Res. Lett., 32, L04311, doi:10.1029/2004GL021646.

Domzig, A. et al., 2006. Searching for the Africa-Eurasia Miocene boundary offshore western Algeria (MARADJA'03 cruise), Comptes Rendus Geosci., 338(1-2), 80-91.

Duggen, S., Hoernle, K., van den Bogaard, P. \& Harris, C., 2004. Magmatic evolution of the Alboran region: the role of subduction in forming the western Mediterranean and causing the Messinian Salinity Crisis, Earth planet. Sci. Lett., 218(1-2), 91-108. 
Dunn, R.A. \& Martinez, F., 2011. Contrasting crustal production and rapid mantle transitions beneath back-arc ridges, Nature, 469(7329), 198-202.

Durand-Delga, M. \& Fontboté, J., 1980. Le cadre structural de la Méditerranée occidentale, Mem. BRGM, 11, 65-85.

Eberhart-Phillips, D., Stanley, W.D., Rodriguez, B.D. \& Lutter, W.J., 1995. Surface seismic and electrical methods to detect fluids related to faulting, J. geophys. Res., 100(B7), 12 919-12936.

Edwards, R.A., Whitmarsh, R.B. \& Scrutton, R.A., 1997. The crustal structure across the transform continental margin off Ghana, eastern equatorial Atlantic, J. geophys. Res., 102(B1), 747-772.

Faccenna, C., Becker, T.W., Lucente, F.P., Jolivet, L. \& Rossetti, F., 2001. History of subduction and back-arc extension in the Central Mediterranean, Geophys. J. Int., 145(3), 809-820.

Frizon de Lamotte, D., Saint Bezar, B., Bracène, R. \& Mercier, E., 2000. The two main steps of the Atlas building and geodynamics of the western Mediterranean, Tectonics, 19(4), 740-761.

Frizon de Lamotte, D., Raulin, C., Mouchot, N., Wrobel-Daveau, J.-C., Blanpied, C. \& Ringenbach, J.-C., 2011. The southernmost margin of the Tethys realm during the Mesozoic and Cenozoic: initial geometry and timing of the inversion processes, Tectonics, 30(3), doi:10.1029/2010TC002691.

Funck, T., 2004. Crustal structure of the northern Nova Scotia rifted continental margin (eastern Canada), J. geophys. Res., 109(B9), B09102, doi:10.1029/2004JB003008.

Gailler, A., Klingelhoefer, F., Olivet, J.-L. \& Aslanian, D., 2009. Crustal structure of a young margin pair: new results across the Liguro-Provencal Basin from wide-angle seismic tomography, Earth planet. Sci. Lett., 286(1-2), 333-345.

Gallais, F., Gutscher, M.-A., Graindorge, D., Chamot-Rooke, N. \& Klaeschen, D., 2011. A Miocene tectonic inversion in the Ionian Sea (central Mediterranean): evidence from multichannel seismic data, J. geophys. Res., 116(B12), B12108, doi:10.1029/2011JB008505.

Gallais, F., Graindorge, D., Gutscher, M.-A. \& Klaeschen, D., 2013. Propagation of a lithospheric tear fault (STEP) through the western boundary of the Calabrian accretionary wedge offshore eastern Sicily (Southern Italy), Tectonophysics, 602, 141-152.

Govers, R.M.A. \& Wortel, R., 2005. Lithosphere tearing at STEP faults: response to edges of subduction zones, Earth planet. Sci. Lett., 236, $505-523$.

Greenroyd, C.J., Peirce, C., Rodger, M., Watts, A.B. \& Hobbs, R.W., 2008. Demerara Plateau - the structure and evolution of a transform passive margin, Geophys. J. Int., 172(2), 549-564.

Grevemeyer, I. \& Ranero, C.R., 2011. Seismic constraints on the nature of crust in the Algerian-Balearic Basin-implications for lithospheric construction at back-arc spreading centres, in Proceedings of the American Geophysical Union, Fall Meeting'11, abstract \#T53D-04.

Gutscher, M.-A. et al., 2012. The Gibraltar subduction: a decade of new geophysical data, Tectonophysics, 574-575, 72-91.

Jolivet, L. \& Faccenna, C., 2000. Mediterranean extension and the AfricaEurasia collision, Tectonics, 19(6), 1095-1106.

Jolivet, L., Faccenna, C. \& Piromallo, C., 2009. From mantle to crust: stretching the Mediterranean, Earth planet. Sci. Lett., 285(1-2), 198209.

Korenaga, J., Holbrook, W.S., Kent, G.M., Kelemen, P.B., Detrick, R.S., Larsen, H.-C., Hopper, J.R. \& Dahl-Jensen, T., 2000. Crustal structure of the southeast Greenland margin from joint refraction and reflection seismic tomography, J. geophys. Res., 105(B9), $21591-$ 21614.

Koyi, H., Jenyon, M.K. \& Petersen, K., 1993. The effect of basement faulting on diapirism, J. Pet. Geol., 16(3), 285-312.

Leprêtre, A., Graindorge, D., Klingelhoefer, F., Schnurle, P. \& Bracène, R., 2011. How atypical is the Algerian passive margin? First results from structures imaged by seismic data off Tipaza, central Algerian margin, in Proceedings of the EGU General Assembly 2011, Vienna, Austria, 2011 April 3-8, Vol. 13, Geophysical Research Abstract TS6.2/GD5.9/GMPV46/SM1.6.

Leprêtre, A., Klingelhoefer, F., Graindorge, D., Schnurle, P., Beslier, M.-O., Yelles, K., Déverchère, J. \& Bracène, R., 2013. Multiphased tec- tonic evolution of the Central Algerian margin from combined wide-angle and reflection seismic data off Tipaza, Algeria, J. geophys. Res.: Solid Earth, 118(8), 3899-3916.

Lofi, J. et al., 2011. Refining our knowledge of the Messinian salinity crisis records in the offshore domain through multi-site seismic analysis, Bull. la Soc. Geol. Fr., 182(2), 163-180.

Lonergan, L. \& White, N., 1997. Origin of the Betic-Rif mountain belt, Tectonics, 16(3), 504-522.

Louden, K., 1980. The crustal and lithospheric thicknesses of the Philippine Sea as compared to the Pacific, Earth planet. Sci. Lett., 50(1), 275-288.

Mauffret, A., Frizonde Lamotte, D., Lallemant, S., Gorini, C. \& Maillard, A., 2004. E-W opening of the Algerian Basin (Western Mediterranean, Terra Nov., 16(5), 257-264.

Mauffret, A., Ammar, A., Gorini, C. \& Jabour, H., 2007. The Alboran Sea (Western Mediterranean) revisited with a view from the Moroccan Margin, Terra Nov., 19(3), 195-203.

Medaouri, M., Bracène, Deverchere, R., Graindorge, J. \& Ouabadi, D., A. \&Yelles-Chaouche, A., 2012. Structural styles and Neogene petroleum system around the Yusuf-Habibas Ridge (Alboran Basin, Mediterranean Sea), Leading Edge, 31(7), 776-785.

Medaouri, M., Déverchère, J., Graindorge, D., Bracène, R., Badji, R., Ouabadi, A., Yelles-Chaouche, K. \& Bendiab, F., 2014. The transition from Alboran to Algerian basins (Western Mediterranean Sea): chronostratigraphy, deep crustal structure and tectonic evolution at the rear of a narrow slab rollback system, J. Geodyn., 77, 186-205.

Meghraoui, M., Cisternas, A. \& Philip, H., 1986. Seismotectonics of the Lower Cheliff Basin: structural background of the El Asnam (Algeria) Earthquake, Tectonics, 5(6), 809-836.

Meghraoui, M., Morel, J., Andrieux, J. \& Dahmani, M., 1996. Tectonique plio-quaternaire de la chaîne tello-rifaine et de la mer d'Alboran. Une zone complexe de convergence continent-continent, Bull. la Société Géologique Fr., 167(1), 141-157.

Michard, A., Chalouan, A., Feinberg, H., Goffé, B. \& Montigny, R., 2002. How does the Alpine belt end between Spain and Morocco?, Bull. la Société Géologique Fr., 173(1), 3-15.

Minshull, T.A., Muller, M.R. \& White, R.S., 2006. Crustal structure of the Southwest Indian Ridge at $66^{\circ} \mathrm{E}$ : seismic constraints, Geophys. J. Int., 166(1), 135-147.

Muller, M.R., Minshull, T.A. \& White, R.S., 2000. Crustal structure of the Southwest Indian Ridge at the Atlantis II Fracture Zone, J. geophys. Res., 105(B11), $25809-25828$.

Pascal, G.P., Mauffret, A. \& Patriat, P., 1993. The ocean-continent boundary in the Gulf of Lion from analysis of expanding spread profiles and gravity modelling, Geophys. J. Int., 113(3), 701-726.

Perrodon, A., 1957. Etude géologique des bassins néogènes sublittoraux de l'Algérie occidentale, edited by Priester frères, Bulletin n ${ }^{\circ} 12 \mathrm{du}$ Service de la carte géologique de l'Algérie.

Platt, J. \& Houseman, G., 2003. Evidence for active subduction beneath Gibraltar: comment and reply, Geology, 31, e22.

Platt, J., Anczkiewicz, R. \& Soto, J.I., 2006. Early Miocene continental subduction and rapid exhumation in the western Mediterranean, Geology, 34(11), 981-984.

Platt, J.P., Soto, J.I., Whitehouse, M.J., Hurford, A.J. \& Kelley, S.P., 1998. Thermal evolution, rate of exhumation, and tectonic significance of metamorphic rocks from the floor of the Alboran extensional basin, western Mediterranean, Tectonics, 17(5), 671-689.

Polvêche, J., 1959. Contribution à l'étude géologique de l'Ouarsenis oranais, Service de la carte géologique de l'Algérie.

Prada, M., Sallarès, V., Ranero, C.R., Vendrell, M.G., Grevemeyer, I., Zitellini, N. \& de Franco, R., 2014. Seismic structure of the Central Tyrrhenian basin: geophysical constraints on the nature of the main crustal domains, J. geophys. Res.: Solid Earth, 119(1), 52-70.

Réhault, J.-P., Boillot, G. \& Mauffret, A., 1984. The western Mediterranean basin geological evolution, Mar. Geol., 55(3), 447-477.

Rosenbaum, G., Lister, G.S. \& Duclos, C., 2002. Reconstruction of the tectonic evolution of the western Mediterranean since the Oligocene, J. Virtual Explor., 8, 107-130. 
Sage, F., Pontoise, B., Mascle, J., Basile, C. \& Arnould, L., 1997. Crustal structure and ocean-continent transition at marginal ridge: the Côte d'Ivoire-Ghana marginal ridge, Geo-Mar. Lett., 17, 40-48.

Sage, F., Basile, C., Mascle, J., Pontoise, B. \& Whitmarsh, R.B., 2000. Crustal structure of the continent-ocean transition off the Côte d'IvoireGhana transform margin: implications for thermal exchanges across the palaeotransform boundary, Geophys. J. Int., 143(3), 662-678.

Sallarès, V., Charvis, P., Flueh, E.R. \& Bialas, J., 2003. Seismic structure of Malpelo and Cocos Volcanic Ridges and implications for hotspot-ridge interaction, J. geophys. Res., 108(B12), 2564, doi:10.1029/2003JB002431.

Sallarès, V. et al., 2011. Seismic evidence for the presence of Jurassic oceanic crust in the central Gulf of Cadiz (SW Iberian margin), Earth planet. Sci. Lett., 311(1-2), 112-123.

Sallarès, V., Meléndez, A., Prada, M., Ranero, C.R., McIntosh, K. \& Grevemeyer, I., 2013a. Overriding plate structure of the Nicaragua convergent margin: relationship to the seismogenic zone of the 1992 tsunami earthquake, Geochem. Geophys. Geosyst., 14(9), 3436-3461.

Sallarès, V. et al., 2013b. Seismic evidence of exhumed mantle rock basement at the Gorringe Bank and the adjacent Horseshoe and Tagus abyssal plains (SW Iberia), Earth planet. Sci. Lett., 365, 120-131.

Schettino, A. \& Turco, E., 2006. Plate kinematics of the Western Mediterranean region during the Oligocene and Early Miocene, Geophys. J. Int., 166(3), 1398-1423.

Schettino, A. \& Turco, E., 2010. Tectonic history of the western Tethys since the Late Triassic, Geol. Soc. Am. Bull., 123(1-2), 89-105.

Sclater, J.G., Karig, D., Lawver, L.A. \& Louden, K., 1976. Heat flow, depth, and crustal thickness of the marginal basins of the South Philippine Sea, J. geophys. Res., 81(2), 309-318.

Spakman, W. \& Wortel, R., 2004. Tomographic view on western Mediterranean geodynamics, in The TRANSMED Atlas, The Mediterranean Region from Crust to Mantle, pp. 31-52, eds Cavazza, W., Roure, F., Spakman, W., Stampfli, G.M. \& Ziegler, P., met CDROm.

Stich, D., 2003. Moment tensor solutions for small and moderate earthquakes in the Ibero-Maghreb region, J. geophys. Res., 108(B3), 2148, doi:10.1029/2002JB002057.

Stockwell, J.W., 1999. The CWP/SU: seismic Un(*)x package, Comput. Geosci., 25, 415-419.

Tarantola, A., 1987. Inverse Problem Theory: Methods for Data Fitting and Model Parameter Estimation, SIAM.

Thomas, G., 1985. Géodynamique d'un bassin intramontagneux: Le Bassin du Bas-Chelif occidental (Algérie) durant le mio-plio-quaternaire, Université de Pau, 594 pp.

Van Hinsbergen, D.J.J., Vissers, R.L.M. \& Spakman, W., 2014. Origin and consequences of western Mediterranean subduction, rollback, and slab segmentation, Tectonics, 33(4), 393-419.

Varela, C.L., Rosa, A.L.R. \& Ulrych, T.J., 1993. Modeling of attenuation and dispersion, Geophysics, 58(8), 1167-1173.
Vergés, J. \& Fernàndez, M., 2012. Tethys-Atlantic interaction along the Iberia-Africa plate boundary: the Betic-Rif orogenic system, Tectonophysics, 579, 144-172.

Verschuur, D.J. \& Berkhout, A.J., 1997. Estimation of multiple scattering by iterative inversion, Part II: practical aspects and examples, Geophysics, 62(5), 1596-1611.

Wessel, P. \& Smith, W.H.F., 1998. New, improved version of generic mapping tools released, EOS, Trans. Am. geophys. Un., 79, 579-579.

White, R.S., McKenzie \& O’Nions, R.K., 1992. Oceanic crustal thickness from seismic measurements and rare earth element inversions, J. geophys. Res., 97(B13), 19683-19715.

Yielding, G., Ouyed, M., King, G.C.P. \& Hatzfeld, D., 1989. Active tectonics of the Algerian Atlas Mountains-evidence from aftershocks of the 1980 El Asnam earthquake, Geophys. J. Int., 99(3), 761-788.

Zelt, B.C., Taylor, B., Weiss, J.R., Goodliffe, A.M., Sachpazi, M. \& Hirn, A., 2004. Streamer tomography velocity models for the Gulf of Corinth and Gulf of Itea, Greece, Geophys. J. Int., 159(1), 333-346.

Zelt, C.A., 1998. Lateral velocity resolution from three-dimensional seismic refraction data, Geophys. J. Int., 135(3), 1101-1112.

\section{SUPPORTING INFORMATION}

Additional Supporting Information may be found in the online version of this paper:

Figure S1. Wide-angle seismic sections used in this work. Each section was processed as in Fig. 3. Each section is shown without interpretation and with picked traveltimes.

Figure S2. Correlation of the $P$ waves reflected from the top of the acoustic basement at near vertical incidence along MCS profile Spi02 and at wide-angle on OBS 14 and 9. The wide-angle reflection traveltimes were used during the tomographic inversion.

Figure S3. Monte Carlo ensemble used as starting model for the simulation. To the left an ensemble of 100 initial Moho is derived randomly from the initial model obtained by forward modelling (red line) with a maximal variation of $\pm 1 \mathrm{~km}$. To the right, the initial 1-D model (red line) is used to derive 100 random initial models with a maximal variation de $\pm 0.5 \mathrm{~km} \mathrm{~s}^{-1}$ (http://gji.oxfordjournals.org/ lookup/suppl/doi:10.1093/gji/ggu454/-/DC1).

Please note: Oxford University Press is not responsible for the content or functionality of any supporting materials supplied by the authors. Any queries (other than missing material) should be directed to the corresponding author for the paper. 